\title{
Literature
}

әАәбият

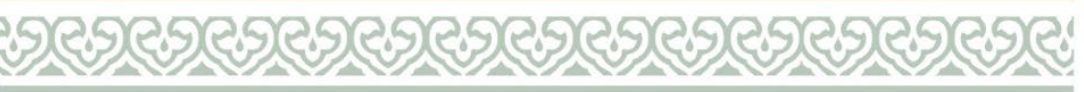

Аитература

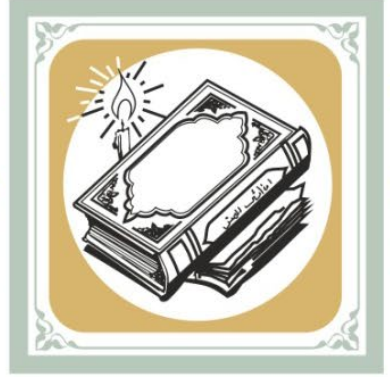

\section{TATAR LITERATURE IN TURKEY: RECOGNITION AND RESEARCH TRENDS}

Birsel Oruc Aslan,

Balıkesir University,

17 Bigadic Yolu Uzeri, Balıkesir, 10145, Turkey, rezeda_raf@mail.ru.

\section{Rezeda Rafailevna Khairutdinova,}

Kazan Federal University,

18 Kremlyovskaya Str., Kazan, 420008, Russian Federation, rezedarraf@mail.ru.

\section{Yusuf Ozchoban,}

Balikesir University,

17 Bigadic Yolu Uzeri, Balıkesir, 10145, Turkey, rezeda_raf@mail.ru.

Aysylu Khusainovna Sadekova, G. Ibragimov Institute of Language, Literature and Art of the Tatarstan Academy of Sciences, 12 Karl Marx Str., Kazan, 420111, Russian Federation, rezeda_raf@mail.ru.

This article provides an overview of the ways of promoting Tatar literature in Turkey, its branches and the level of study. Attention is drawn to the scientific problems and research topics. The article clarifies the status of scientists and intellectuals who have made significant contributions to the popularization and promotion of the spiritual national treasury among fraternal peoples. There is information about the quality and quantity of scientific research devoted to the Tatar verbal art in Turkish literature studies. At the same time, we identify the prospects of searches in this direction in the future and the ways of Tatar literature development in Turkey.

Key words: Tatar literature, Turkey, literary research, literary connections, translation, promotion. 


\section{Introduction}

The proximity of languages, one of the main indicators of the national unity of the Tatar and Turkic peoples, ensures the stability and continuity of their literary and cultural ties. Despite different social and cultural conditions, these two nations are interested in their culture and verbal art, moreover, they enrich each other with ideological and aesthetic values in the national literature. The first connections between the Tatars and Turks are associated with the people who fled to Turkey after the capture of the Kazan khanate by Ivan the Terrible in 1552 and came back later, and Tatar clergy who made the Hajj, [Bargan, Gilazov, 2014, p. 73], [Bargan, 2015]. In Turkish society, the level of Tatar literacy has always been high. In the Middle Ages, spiritual and cultural ties between the peoples of Anadolu and the Volga-Ural regions strengthened. Books written in Anadolu were willingly read in the Volga-Ural region and, conversely, were gladly accepted and highly appreciated in Anadolu. At the beginning of the $20^{\text {th }}$ century, one layer of philosophical and social ideas of Tatar intelligentsia, permeated with Russian revolutionary spirit, penetrated into Anadolu.

Tatar verbal art, which developed under the influence of Oriental literature, as well as Turkish literature, in the second half of the $19^{\text {th }}$ century turned to the culture of the West and accepting its modernized ideological content and artistic design. A new Tatar prose was formed, creating free-form poetry in addition to novels and short stories. Still, Turkish literature had a very strong influence on Tatar literature of the Education period.

It is known that such Tatar writers as Zakir Ramiyev, Fatih Karimi, Galiasgar Kamal, and Sharif Kamal, came to Turkey with the aim of mastering the achievements in Turkish culture and literature and gaining world knowledge, i.e. there were wide opportunities for familiarizing themselves with Turkish literature. The encyclopedic scholar and writer Rizaetdin Fakhretdin thoroughly studied Turkish literature, its outstanding personalities and thinkers. He wrote a monographic work about the famous Turkish writer, scientist, philosopher, mathematician and public figure Ahmed Midhat Efande after his death [Fakhrutdin, 1913].

This process, especially intensified in the late $19^{\text {th }}$ - early $20^{\text {th }}$ centuries, and understandably weakened in the Soviet times. The perestroika of the 1985s opened up new possibilities for the revival and strengthening of literary and cultural ties between the fraternal peoples. In 1989-1990, the Turkic peoples gained independence and estab- lished their own republics. Turkey and Tatarstan, which is not an Autonomous Republic, but only an integral part of Russia, resumed relations. Both sides began to cooperate in economic and cultural areas.

In this regard, the interest in the Tatar language and literature grew in Turkey and gave impetus to individual studies in this area. Most of the scientific research belongs to the field of language, in synthesis with history and the writers' creative work. However, they ended up in the centers of scientific papers, or in the archives of the universities, without reaching a wide audience as they were handwritten manuscripts. Taking these circumstances into account, the article observes and assesses the level of distribution and study of Tatar literature in Turkey, to a certain extent focusing on the works in the field of linguistics.

In the early twenty-first century, the conversance of the Tatar literary art achievements by different strata of Turkish intelligentsia took different forms. Translation is one of the most effective means of studying the level of literary and cultural development, the spirituality of other peoples, the exchange of language and morality. It facilitates the establishment of internal and external spiritual ties and strengthens ties between peoples who do not have a common language and religion. At the beginning of the twentieth century, the state took the lead in strengthening spiritual and cultural ties with the Turkic-fraternal peoples. A good example of this is the fact that the classics of Tatar literature, modern writers, translated into Turkish, were published in the form of a separate book. Since 2005, the works of Tatar literature have been translated into Turkish and regularly appear in Turkey. Literary critics F. Sayfullina and A. Valeeva discuss this issue in detail in their research work [Sayfullina, Valeeva, 2017].

It is most gratifying that the deep content and artistic design characterizing the Tatar writers' works, which could hold a place of honour in the world's verbal Treasury, did not leave Turkish creative figures indifferent. In order to convey this spiritual wealth to their people, a group of Turkish intellectuals studied the Tatar language to translate beautiful samples of our national literature into Turkish: among them are M. Oner, F. Kutlu, etc.

The Turkish World Research Foundation published R. Mukhamadiev's book "Sirat Bridge" translated by Mustafa Oner in 1993 [Mukhamadiev, 1993]. The book describes the life of M. Sultangaleev and the Tatar people's struggle for their independence. In addition, M. Oner trans- 
lated the writer's journalistic work "Russian Democracy", written in 1990-1995 on the basis of parliamentary records [Mukhammadieva, 1996]. In this book, published in 1996, with the support of "Ituken Publications", R. Mukhamadiev describes the process of democratization in Russia during the period from 1989 to 1995 .

The familiarity of Turkish readers with Tatar literature begins with small epic genres. The collection of them "Vasiyet" ("Testament") was published in Zambak publishing house in 2005, 2006 and 2012 [Vasiyet, 2012]. The translators of the works collected in the book are Fatih Kutlu, Hamza Ersoy, and Nadir Tamar Arslanov. The collection includes the best examples of Tatar short novels: A. Eniki's ("The Undeclared Will", "Beauty"), Sh. Kamal's ("Buranda", "Uyanu"), F. Amirkhan's ("In One Haraba", "Samigulla Abzy"), G. Ibragimov's ("The Children of Nature"), M. Amir's ("A Carefree Old Dream"), F. Husni's (“A Vast Story"), M. Yunus's ("Our House Was under the Osiers"). In 2007, the works of R. Valeev, translated by Fatih Kutlu and Harun Tosun, were published in the Turkish publishing house "Da" entitled "Mavi hüzün" ("Blue Sadness") [Mavi Hüzün, 2007].

Referring to different periods of the Tatar literature development, translators constantly inform Turkish readers about the thematic space, genre diversity and literary connections in the national verbal art. Ch. Zaripova and H. Yilmaz, for example, translated the works of G. Ishaki, through which social and nation-wide topics run like a golden thread in addition to the universal values (Ishaki, 2009). F. Kutlu translated the works of M. Mirza [Mirza, 2009], and the lyrical poet R. Hatash who revived the traditions of the ghazal and Ruba'i genre in Tatar poetry [Gatash, 2011: Ruais...], [Gatash, 2011, On the eternal path...]

In her article, F. Saifullina dwelt in detail on the translator and philologist Fatih Kutlu, who was admitted as a member of the Union of Tatarstan Writers and whose work was highly praised: "Fildişi Çakı (Tatar çocuk hikayeleri)" (Children's Stories) translated by F. Kutlu [Fildişi Çakı, 2013] and the short story collection "Sessiz Kuray" ("Silent Kuray") [Sessiz Kuray, 2013] were published in "Bangu" publishing house. R. Batulla's fairytales [Cengâver Alp'in Kahramanlıkları, 2013] and the collection of short stories "Altın Sincap" ("The Golden Squirrel”) [Altın Sincap, 2014] translated by him reached Turkish readers (Saifuulina, Valeeva, 2017, p. 54). The latter includes the works of writers N. Dumavi, A. Alish, G. Rahim,
D. Appakova, L. Ihsanova, F. Valeev, F. Amirkhan and others. Thanks to his efforts, R. Zaydulla's work "The Old Man with the White Ependytes" is available to Turkish readers [Zaydulla, 2016]. A number of stories by Tatar writers, those which have preserved universal values and traditions that are passed down from generation to generation, are listed by the Ministry of Education in Turkey among hundreds of books obligatory for reading by pupils: among them are the stories by A. Eniki "The Undeclared Will" and "Beauty".

According to F. Sayfullina, the poetry of Gabdulla Tukai is one of the works that made F. Kutlu famous as a translator of Tatar literature into Turkish. Before that, the Tatar national poet had not been translated into Turkish on that scale. For 10 months F. Kutlu and his colleague A. Akbash Bey were responsible for this work. To mark the $130^{\text {th }}$ anniversary of the national poet, his 130 poems were selected with the support of the poet and writer R. Zaydulla (Sayfullina, Valeeva, 2017, p. $55)$.

The growing literary skills and translation experience enabled Fatih Kutlu to take on more complex works. He has made a great contribution to the promotion of Ayaz Gilazov's work in Turkey. The first acquaintance of the translator with the writer occurred through his work, as he states in the preface to the book. Kutlu has translated the works "Three Arshins of Land" ("Bir avuç toprak"), [Ğıylecev A. Bir Avuç Toprak, 2008; 2011], "On Friday Evening..." ('Cuma günü, akşam...") [Çıylecev A. Cuma günü, akşam..., 2013].

As you know, these works brought A. Gilyazov fame as a writer, he was awarded a prize in the field of fiction "The Prize named after Gabdulla Tukay". Ayaz Gilyazov was a great writer who through his works sought to create a happy life. He was convicted and punished for speaking out against the ideology of Stalin. By translating the author's works from Tatar into Turkish, Kotlu fulfilled his sacred wish. In 2012, Eurasian Writers Society presented Kotlu's work "Three Arshins of Land" with the award the "Best translation of the novel'. Thus, the works of Ayaz Gilazov found their readers among the Turkish audience and entered the scientific turnover. Of course, the successful activity of F. Kutlu in the field of translation is of utmost importance here. It was through his translations that the works of the Tatar writer could be read in the Turkish language. One of the last Fatih Kutlu's translated works was the book "Soundless Kuray" (2013), which comprised se- 
lected works from modern Tatar literature [Sessiz Kuray, 2013].

"As a translator, F. Kutlu is interested in various literary and historical periods of Tatar literature, - the article says, - among the translated works there are examples of Tatar poetry and prose of the early $20^{\text {th }}$ century (G. Tukay, G. Ibragimov, F. Amirkhan, Sh. Kamal), Tatar prose of the Great Patriotic War (A. Alish), prose and poetry of the second half of the $20^{\text {th }}$ century (F. Husni, A. Gilyazov, R. Valeev), and modern Tatar literature (R. Batulla, R. Zaydulla) [Saifullina, Valeeva, 2017, p. 55].

In May 2014, the collection of poems by G. Tukai "Kaitu", translated by Birsel Oruж Aslan and Yusuf Ozchoban, was released by the publishing house "Komen Publications" [Tukai, 2014]. The book includes translations of works taken from the publication "I Come to Tukai", which the writers of different times dedicated to the great poet after Tukai's death. The original version of this book was created by Gulzada Bayramova and published in 1996.

Translation of Tatar outstanding writers and poets' works into Turkish is one of the ways, the primary stage of popularizing Tatar literature and its spiritual values among readers and literary community. In the following years, serious steps were taken in literary studies of Tatar literature in Turkey. A group of scholars embarked on studies of Tatar literature and achieved impressive results. The efforts of Turkish scholars, who realize the richness of Tatar literature and study the Tatar language to explore different periods and literary issues of national literature, are quite commendable and should be recognized.

Huseyn Bargan, a Turkish literary scholar in the faculty of the Turkish language and literature at the Institute of Humanities in Istanbul, successfully works in this direction. He comes to the Republic of Tatarstan, collects rich material working in its libraries, archives, thoroughly studying various sources and literary materials. H. Bargan was initially recognized as the author of research articles on Tatar literature, later he went on to write a monographic work. The result of his scientific research is the work "The Influence of Turkic Literature on Tatar Literature in the Volga-Ural Region (1860-1917)" [Bargan, 2015]. The monograph covers the period of 1860 to 1917 years in Tatar literature, when social and cultural conditions for the revival of national verbal art were created. The author emphasizes the positive influence of Turkish culture and literature on Tatar literature in the con- text of spiritual and social cultural relations, existing at the turn of the two centuries. In this regard, he portrays the personalities of Tatar philosophers, representatives of public thought, religious reformers, and writers and poets Z. Ramiev, F. Karimi, Sh. Kamal, G. Kamal, and G. Tukay. Their life paths and their literary worlds are enriched with new data.

The book "Poems of Gabdulla Tukay (analysistranslations)" was published by Fatma Ozkan in 1994 [Ozkan, 1994]. This work was developed on the basis of Ozkan's doctoral dissertation at the Institute of Social Sciences of Ghazi University. The thesis consists of the following parts: introduction, Kazan Turks, life and literary works of Gabdulla Tukai. The first part contains a meaningful description of the poems by Gabdulla Tukay, the second is devoted to the poet's poetic style and form analysis. This work, dedicated to Tukai and his work, is one of the most comprehensive studies. Tukai is considered to be a great master of Tatar poetry, although he lived in the world for only 27 years. $\mathrm{He}$ is an outstanding Tatar poet.

"The Collection of Tatar Songs (Preface - texttranslation - subject index)" was published by Erdal Shagin in 1999 [Shaheen, 1999]. This work, based on the master's thesis on a scientific problem named after the book, was prepared for publication in 1997 at the Institute of Turkish Studies at Marmar University. The introduction, which contains basic information, is divided into three parts. Translations of texts form a large part of the study. Long folk songs, short folk songs, literal songs giving transcriptions and translations into Turkish are presented under three names. The conclusion goes along with the dictionary.

Persistent steps are also being taken to acquaint the Turkish reader with Tatar works of oral folk art, which plays a fundamental role in the formation of world verbal art, including Tatar literature. In 2005, the scientific work of Mustafa Oner, known for his works on the Kipchak group, "Tatar Two-Lines Couplets" [Oner, 2005], was published. It contains 500 songs in Latin, transcribed and translated into Turkish. They were chosen from 5630 songs from the book of folklorist N. Ilbaris "Short Songs" (colorful four-line folk rhymes). This work of the scientist on Tatar songs is considered to be major research in this area. At the beginning, M. Oner places two-line couplet texts with a brief analysis. At the end, the book has a transcription and translation of the song lyrics and a dictionary in the form of a separate unit. 
The songs of Kazan Tatars, translated by S. Kachalin, were first heard from prisoners during the war of 1914-1918 and recorded by Ignacy Kunos [Couplets of Kazan Tatars, 2013]. Zhuzha Kakuk prepared this collection for publication. This manuscript, which includes two-line couplets is translated into three languages, i.e. Tatar, Turkish, Hungarian and consists of 212 pages. All materials contain 635 verses and most of the entries are placed at the end of the paper.

At the turn of the $20^{\text {th }}-21^{\text {st }}$ centuries, for known reasons, Tatar intellectuals of different classes moved to Turkey and formed a Tatar Diaspora there. Among them are scholars of Tatar literature, linguistics and history, educated in the Tatar scientific academic school. Chulpan Zaripova-Chetin, Associate Professor of Turkic languages and literature in the faculty of Humanities, Caucasus University in Kars, is distinguished by her enthusiastic scientific activity. Her research object is the writers of the early $20^{\text {th }}$ century and Soviet writers. At the same time, the scholar focuses on folklore, especially on the study of national traditions. Her monographic work "Tatar Türklerinin Gelenek ve Görenekleri" introduces Turkish readers to the traditions and customs of the Tatar people [ZaripovaÇetin, 2009]. In the work "Ibrahimov'un Eserlerinde Tatar, Başkurt ve Kazak Türklerinin Kültürel Değerleri" she examines the reflection of spiritual values of Tatars, Bashkirs, Kazakhs in the works of G. Ibragimov, an outstanding writer of the early twentieth century [Zaripova-Çetin, 2009].

Some results of Ch. Zaripova- Çetin's scientific research occupy a place on the pages of the scientific journal. Among them, in addition to the articles covering the works of folk oral art [ZaripovaÇetin, 2007], is research into traditions of the Tatar people, ethnographic privileges [Zaripova-Çetin, 2009], "Idegey" [Zaripova-Çetin, 2007], the poetry of R. Gatash from the point of Eastern traditions, and the works of M.Yunys [Zaripova-Çetin, 2009].

As known, every higher school in Turkey publishes its own journal for the publication of works on social and humanitarian issues. "Türklük Bilimi Araştırmaları Dergisi", "Türk Dünyası Dil ve Edebiyat Dergisi", , "Kardaş Edebiyatlar Dergisi", "Milli Folklor Dergisi", "Firat Üniversitesi Sosyal Bilimler Dergisi", "Türkoloji Araştırmaları Dergisi”, “Atatürk Üniversitesi Türkiyat Araştırmaları Dergis", "TÜRKSOY Türk Dünyası Kültür, Sanat, Bilim, Haber ve Araştırma Dergisi", "Çukurova Üniversitesi Sosyal Bilimler Enstitüsü Dergisi", "İstanbul Üniversitesi Edebiyat Fakültesi Dergisi" and others. They present numerous theo- retical, problem and review articles related to the Tatar language, literature, folklore, history. The works of R. Yarullina-Yildirim, E. Shagin, A. Kamalieva and others are published in the abovementioned journals.

R. Kurban is also distinguished by the activity and effectiveness of his scientific activities. His publications thematically include prominent writers and poets of various literary and historical periods of Tatar literature: Kayum Nasyri [Kurban, 2014, Tatar intelligentsia...], Dardemd [Kurban, 2014, On the $150^{\text {th }}$ years of birth...], A. Eniki [Kurban, 2014, Tatar literature...], F. Yarullin [Kurban, 2017], M. Magdeev [Kurban, 2015], N. Safina [Kurban, 2019], etc.

The issue of training scholars from the Turkish branch of Philology and folklore of the Turkish community has been seriously discussed. When high school students graduate, they present their thesis, masters write a master's thesis. All dissertations and topics are submitted to the center for scientific services and appear on its website in chronological order. The topics of scientific research relate to various branches of Tatar literature, language and Turkology, and to folklore.

Mustafa Oner completed his thesis "Galbdulah Tukay's Poems" at the Institute of Social Sciences, Dokuz Eylul University in 1990 [Oner, 1990]. However, there could not be found any information concerning his thesis in the database of the Higher Education Thesis Data Center before.

Hatidje Shirin completed her thesis on Hesen Tufan's Poems and Text Dictionary in 1998 [Shirin, 1998]. The purpose of her studies is to familiarize readers with Hesen Tufan and his poems. Being one of the greatest poets of Tatar literature, Tufan wrote lyrical poems about his motherland. Because of his poem he was accused of nationalism and of organizing a coup against the Communist revolution, and as a result was sentenced to death. However, immediately after the sentence he was exiled. Shirin prepared her thesis in three parts. In the first introductory chapter she describes Hesen Tufan's life, social and literary circles that prepared the poet, and focuses on the features of his general poetic language. In the second chapter of her thesis she transcribes into Turkish the poems in publications of Selection I-II. In the last chapter we can find a dictionary generated from texts and a conclusion.

Goksel Akcha completed his Master's Thesis on "Enchanted Fairy Tales" (Magic Stories) "Evaluation of Tatar morphological characteristics in the texts in 2000" [Akcha, 2000]. The thesis 
consists of four chapters: Introduction, Analysis, Text, and Interpretation. General information and different varieties of tales are discussed in Introduction. Morphological characteristics of "Enchanted Fairy Tales" and their examples are described in the Chapter of Analysis. You may find examples of texts in the Chapter "Text" and translation into Turkish in the Interpretation Chapter. There may be seventeen types of texts of "Enchanted Tales". All texts in his research were translated into Turkish by Akca.

"Fairy Tales about Animals (Animals Fairy Tales). Peculiarities of Evolution of Tatar Sounds in the Texts" was written by Huri Dursun in 2001 [Dursun, 2001]. The main purpose of the research is to identify the peculiarities of Tatar Turkish sounds based on the texts of tales. The research thesis consists of four parts: introduction, analysis, texts, and interpretation. After the introduction comes the chapter of analysis where the examples, given for the determination of the sound characteristics, are compared with the old Turkish and Modern Turkish. In the main part 33 tales are transcribed. Then these 33 tales are translated into Turkish in the interpretation part of the thesis.

In 2004, under the supervision of Prof. Dr. Yavuz Akpınar, Ayshen Uslu prepared her doctorate thesis Modern Tales and Novels in Tatar Literature (the end of the $19^{\text {th }}$ century and the beginning of the $20^{\text {th }}$ century), where she presents information about Tatar literature and focuses on certain issues in the tales [Uslu, 2004]. The research describes the state of Tatar literature in the early $20^{\text {th }}$ century and emphasizes its links to Turkish literature. She gives a general idea to those who want to read these works and shows the importance of these works.

"Compassion" (Transcription, Interpretation, Text Grammar, Dictionary) thesis was prepared by Gulsemin Kap in 2004 [Kap, 2004]. The novel "Compassion" that provides information on the modern Tatar language and the Tatar literary language belongs to Medine Malikova. The research consists of three parts: the studies of language peculiarities, transcription, and translation of the text into Turkish. There is also a dictionary at the end of the thesis. Language studies in the text are focused on sounds studies and morphological studies. Transcription and Translation of the text into Turkish are mutually provided. The original text written in Cyrillics is found at the end of the thesis.

Tatar Turkish, Remzi Veliyev's "Tragedy" (Analysis-Text-Dictionary) thesis was completed by Selda Turhan Arslan in 2006 [Arslan, 2006].
Despite the difficulties that Tatar Turks experienced, there was protection of national assets, which was described in the conflict novel "Tragedy" that was translated into Turkish. In general, the story depicts the tragedy of Turks during the Soviet times; in particular, we see its reflection in Tatarstan. The novel shows Tatar intellectuals, especially noble families, who were persecuted by Stalin. The novel focuses on Tatars, the history of Tatar Turks, different aspects of Tatar Turks' life, Tatarstan, the Kazan Tatar Turkish language and literature of the Kazan Tatar Turks. The main subject of the novel "Tragedy" itself is the studies of Tatar Phonetics, Morphology and Word Formation. At the end of the thesis there is transcription of the text. You can also find a dictionary at the end of the thesis.

Ozlem Ozmen completed his thesis entitled "The Vocabulary of the Novel 'Kazakh Daughter" by Galimdjan İbrahim (Introduction-TextConcordance) in 2006 [Ozmen, 2006]. Alimdjan Ibrahim's novel "Kazakh Daughter" is well known in the Volga-Ural region and in general it is a wellknown name in the history of the Enlightment of Turkic world. Alimdjan İbrahim, primarily belonging to the Tatars, is a popular author recognized by the whole Turkic world. The subject of the research is the language used by Alimdjan Ibrahim in his novel. The texts used in "Kazakh Daughter" were published based on Arabic alphabet. The thesis consists of four parts, in the first part you can find general characteristics of Tatar literature of the $20^{\text {th }}$ century, the information on the author's life and works, and the works devoted to the studies of the author. The second part of research comprises the texts taken from the novel, which were written in Tatar and in Turkish. The third part consists of the dictionary under the directory title, the list of special key words and finally the list of frequently used words. The final part of the research includes the results of the analysis of the issues discussed in the study.

Arife Gulsun finished her research thesis, named "Vocabulary in Ayaz İshaki's Two Stories "The Soonest is in Two Centuries" and "The Dungeon" (Introduction-Text-Concordance), in 2006 [Gulsun, 2006]. The leader of the Volga-Ural National Liberation Movement, the journalist and writer Ayaz İshaki worked throughout his life for the happiness of the Tatar people, fearlessly endured all the hassle. Ishaki's novels under study belong to the early years of his literary career. When determining the vocabulary mentioned in two stories, the internal structure of the stories was 
taken into consideration. The thesis consists of five parts. Ayaz Ishaki's life and life cycles are analyzed in the introduction. In the main part you may find two stories written in Latin script, followed by their translations into the Turkish language. In the next part of the thesis an indexed dictionary of the vocabulary of stories can be found. Gulsun has divided the directory part of the research into 4 parts: custom names, frequent words, quotes, additional concordance. The data obtained were analyzed in the final part of the thesis.

Fatma Erish Soyturk prepared her thesis named "Medgit Gafuri's Poems" (Introduction-TextConcordance) in 2006 [Erish Soyturk, 2006]. This study is focused on one of the most famous Tatar and Bashkurt poets Medgit Gafuri, who was born in Ufa in 1880 and wrote his poems in the early thirties of the $20^{\text {th }}$ century, his literary personality and peculiarities of his writing style. Being an important follower of Abdullah Tukay, Medgit Gafuri reflected classic and folk poems of Tatar and Bashkurt literature in his remarkable poems. The study is based on Gafuri's six books of poems that were published in Arabic letters in the period from 1909 to 1918. Soyturk organizes her thesis into four parts. Peculiarities of Tatar literature at the beginning of the $20^{\text {th }}$ century and Gafuri's place in it are discussed in the introduction. The main part of the thesis includes authentic texts of poems written in Arabic, their transcription and translation; the concordance includes a dictionary, custom names, lists of quotes and frequently used words.

Ayhan Kose completed the translation and the role of adjectives-verbs in Rinat Muhammedin's novel "Canary is a Cage Bird", as well as the study of the Tatar Turkish language peculiarities in 2007 [Kose, 2007]. In his work, the language of the novel is analyzed, especially in terms of adjectives and verbs. This study presents the translation of this novel into Turkish in an original way. The thesis consists of two parts; in the first part, after giving information about the author, provides general information about Kazan Tatar Turks and their literature, and after giving general information about the Tatar language, the language of the literary piece, especially adjectives and verbs, is analyzed. The translation of the literary piece is given in the second part of the research. The novel consists of thirty nine chapters. These sections are given individually in the study. It must be due to the extensive volume of the novel that has not been translated into Turkish before.

Vedat Kartaldgyk completed his $\mathrm{PhD}$ thesis on the following theme "The analysis of the language in Sherif Kemal's Novels "Seagulls" and "At Dawn" (Introduction-Analysis-TextConcordance)" in 2008 [Kartaldgyk, 2008]. The state of Tatar literature in the $19^{\text {th }}$ and $20^{\text {th }}$ centuries, Sherif Kemal's life, information on the art and literary works are discussed in the introduction. Yet, the first part includes various features of the texts considered in the study. The second part covers a wide range of grammatical issues. This part is also the core of the research. In the third part of the thesis we can find the translation of the novels into the Turkish language. The list of words, the list of custom names, the list of quotes and frequently used words can be found in the concordance, which is divided into four parts. The grammatical units of the novels with statistical information are given in the conclusion, language statistics of the novels is also provided.

Yusuf Ozchoban completed his thesis on İbrahim Salahov's novels "Kolyma Stories" and "Kukchetav Dalalarynda" (Introduction-TextDictionary and Concordance) in 2008 [Ozchoban, 2008]. Ibrahim Salahov is one of the most prominent Tatar writers of the $20^{\text {th }}$ century. In accordance with the repressive policies of the Stalin era he was one of the punished innocent intellectuals. The study analyzes Ibrahim Salahov's original novels "Kukchetav Dalalarynda" and "Kolyma Stories" that won him fame. The researcher tried to identify both the author's language and style when translating these two novels into Turkish. The study possesses a very detailed analysis of both novels. Ozchoban has also translated and partly published such novels as "Kolyma Stories", "Kolyma Prisoners", "Exile Memoirs of a Tatar Intellectual".

In 2009, Hayrunisa Topchu completed her Master's thesis "The Analysis of Rizaeddin bin Fahreddin's Story "Ahmed Midhat Efendi'" [Topchu, 2009]. The study includes such parts as introduction, text and analysis. The translation of the novel to the Turkish language is given in the main part. As the author is not very well known in Turkey, the researcher gives detailed information about him in the analysis part. The summary of the texts was also included into its analysis. The language and the style of the novel are also analyzed here. The research is finished with the analysis, conclusion and bibliography list.

Another research on Tatar Literature is done by Mustafa Gultekin in 2010, the theme of his PhD thesis is "Research on Tatarstan Tales" [Gultekin, 2010]. In this study Tatar tales are analyzed in terms of shape, structure, content and function pe- 
culiarities. After giving general information on the Tatars and Tatar tales in the first part, the researcher explains the concept of Tatar tales and their emphasis in the Turkic world; the second section of the thesis provides information about the event types described in Tatar tales; the third part examines the motif structure of Tatar tales. The fourth part describes the forms used in Tatar tales. The Conclusion, Bibliography and Index list of the final analysis are given at the end of the study together with the texts of translations into the Turkish language.

Omer Kuchuk Mehmetoglu finished his research named "Analysis of Vocabulary Terms in Musa Jarullah Bigiyef's story "Dîvân-1 Hâfız" in 2010 [Kuchuk Mehmetoglu, 2010]. The study identifies and determines the vocabulary used by Bigiyef in the story "Divan-I Hafiz". The use of the vocabulary shows the similarities between Kazan Turkic literature and Osman Turkic literature. As a result of this comparison, the story, published in Kazan, was widely read and well understood in Istanbul. Introduction of the thesis gives general information on Musa Jarullah and his literary piece of work. In the first part of the thesis, Arabic letters of the text are substituted into Latin letters. In the second part of the thesis, the text written in Tatar is translated into Turkish. In the third part, the vocabulary of "Dîvân -1 Hâfız" is compared with the vocabulary of the Osman Turkish language.

Shirin Aksoy finished her research thesis on "The Analysis of the Language in the Novel "The Path of Life" by Tatar author Garif Ahunov (Introduction-Text-Concordance)" in 2011 [Shirin, 2011]. Being both an important writer and an important statesman, Garif Ahunov inspired people towards doing good things and worked for the benefit of his people. In the center of the novel is an ideal man. This ideal man struggles with negativity by means of honesty, sacrifice and hard work. Aksoy divided the research into four main parts: Introduction, Text, Concordance, and Conclusion. The study describes the author's life with the emphasis on his literary personality and a general view on the Tatar literature of the $20^{\text {th }}$ century. Further, the analysis of the text language is given. The transcription and translation of the text into Turkish are in the main part. Every single word of the text may be found in the concordance. The results of the language analysis are given in the conclusion.

The research thesis on Sibgat Hekim's Poems (Introduction-Text-Concordance) was written by Ulku Polat in 2011 [Polat, 2011]. This research, consisting of 1449 pages, is quite enormous. After presenting some information about the poet in the introduction, the situation of the year 1905 and the state of Tatar literature are briefly explained, followed by the information on the author's biography and his direction in literary art. In the introduction, the list and catalog of poems are given. In the main part of the research, you can find examples of poems both in the authentic Tatar language as well as their translations into the Turkish language. In the concordance part, explanation of the words, used in the poems, is given and the detailed information of their location is presented. The research thesis finishes with a conclusion.

The analysis of poet Zolfet's poems (Introduction, Text, Concordance) was prepared by Seher Memish in 2012 [Memish, 2012]. The thesis is divided into five parts: Introduction, Main Part, Glossary, Conclusion and Bibliography. The introductory part includes information about the life of Zolfet, the language and the topics used in his poetry. The introductory part is followed by the main part, where the author presents the poems from the selection of poems "Among the Forests". At the end of the thesis translated versions of the poems in Turkish can be found. The glossary includes all the words mentioned in the poems.

Serap Karakylych Aky finished his Doctorate Thesis "Language and Style" in Aliasgar Kemal's Theatre Works in 2013 [Karakylych Aky, 2013]. This study reveals one of the most important names in Tatar literature, the founder of the Modern Tatar theatre Aliasgar Kemal and his language and style characteristics in the theatrical texts. The thesis consists of the introduction, description of Aliasgar Kemal's life and works, analysis, conclusion, bibliography, dictionary and parts of the texts. After presenting general information on the theatre in the introductory part, cultural and literal environment, in which the author was raised, is described. The whole life and works of Aliasgar Kemal are depicted in Part I and are presented under different headings. Part II of the Thesis analyzes the author's language and style characteristics of his plays. This part studies language spelling characteristics, word selection, and sentence techniques. In each of the above sections, the author draws attention to the specific usage and differences. You can find the results of the analysis in the conclusion as well as the transcripts and translations of the texts in the main part; there is a dictionary at the end of the thesis to help you understand the texts. The texts are based on Aliasgar 
Kemal's twenty selected drama. These texts have been translated into Turkish.

The analysis of the language of the novel "Repentance" by Tatar author Telgat Galiullin (Introduction-Text-Concordance) was prepared by Erman Aydoganlar in 2013 [Aydoganlar, 2013]. The research of the thesis is done on the novel of a well known Tatar writer, also known as a "public writer", Telgat Galiullin. This novel was written in 1997. The study consists of three main parts: Introduction, Text (the main part), and Dictionary. The introductory chapter provides general information about the author's life, his literary personality and information concerning his literary works. In the main part you can find the text transcribed in Latin letters and the translation of the novel into the Turkish language. The grammatical index can be found in the concordance.

If we look at the studies done so far on the Tatar language and Tatar literature, we see that a big amount of research has been done in language studies whereas there is a smaller amount of research on Tatar literature. Some of the research has been done within the scopes of some Universities and hidden from public. Ege University and Gazi University are at the top of this list. Scientific theses on Tatar language and literature were written and are to be written in Celal Bayar University, Firat University, Sakarya University, and Balikesir University. The names of the consultants under whose supervision Master's and Doctorate theses were written are also to be mentioned.

Summing up the results of the study, we can say that, despite the strong influence of Western literature, spheres of distribution, in Turkey there is a growing interest in Tatar art. Turkish readers and the literary community are interested in the work of Tatar classics, such as G. Tukay, F. Amirkhan, G. Ibragimov, Sh. Kamal, A. Eniki, as well as modern writers R. Gatash, R. Valeev, M. Galeev, G. Gilmanov, R. Zaydulla, etc. Among the translations are: "Three Arshins of Land" ("Bir avuç toprak") and "On Friday, in the Evening." ("Cuma günü, akşam...”) by A. Gilazov, describing the complex spiritual world of the man of the twentieth century, the national qualities of a rural man, rich, alas, the one who has lost his spiritual and cultural wealth.

The studies carried out by researchers of literature and language, turkologists of different states play a great role in familiarizing readers with the Tatar literature, its rich history, national features, in promoting this valuable heritage in Turkey. Decisive steps are being taken to familiarize the Turk- ish literary community with Tatar folklore, its genres and themes based on written literature. In this respect there is particular interest in identification of songs, fairy tales, and dastans genre systems. Also, Turkish writers get acquainted with Tatar literature in these scientific papers, its literary and historical periods, as well as life, creative privileges of the outstanding writers, figurative and pictorial features of their works.

In the future, Turkey will continue reading the works of the famous $20^{\text {th }}$ century authors, such as Karim Tinchurin, Fatih Karim, Fatih Amirkhan, Mukhammat Magdeev, Kavi Najmi, Sajida Suleymanova, as well as other classics of world literature. We would like to believe that this area will expand the scope of scientific research, which, in turn, will strengthen confidence that it will serve to strengthen spiritual, literary, cultural and scientific ties between the two fraternal peoples.

\section{References}

Altın Sincap (2014). [The Golden Penny: Children's Stories]. Тәгж. A. Akbash, F. Kutlu. 293 p. Ankara, "Bəngy" nəshr. (In Turkish).

Akcha, G. (2000). Tylsymly akiyatlar (Tylsymly hikayalor) Tekstlarda Tatar morfologik harakteristiklarny boialoy [Enchanted Fairy Tales (Magic Stories). Basylyp chykmagan magistrlyk dissertatsiyase, Gazi universitety, Iжtimagyy fənnər instituty. Ankara. (In Tatar)

Aksoi, Sh. (2011). Tatar avtory Garif Akhunovnym "Tormysh yuly" romanyn analizlau (keresh - tekstnyy bibliografik kyrsatkeche) [The Analysis of the Language in the Novel "The Road of Life" by Tatar Author Garif Ahunov (Introduction-Text-Concordance)]. Basylyp chykmagan magistrlyk dissertatsiyase, Ege universitety Iжtimagyy fənnər instituty. Izmir. (In Tatar)

Arslan, S. (2006). Ramzi Valiev - tragediia (analiz tekst - syzlek) [Ramzi Valiev-Tragedy (analysis-textdictionary)]. Basylyp chykmagan tatar-terek dissertatsiiase. (In Turkish)

Aydoganlar, Erman (2013). Tatar avtory Tolgat Galiullinnyң, “Toybə” romanyn analizlau (keresh tekstnyy bibliografik kyrsatkeche) [The Analysis of the Language in the Novel "Repentance" by Tatar Author Telgat Galiullin (Introduction-Text-Concordance)]. Basylyp chykmagan magistrlyk dissertatsiyase, Ege universitety, Iжtimagyy fənnər instituty. Izmir. (In Tatar)

Bargan, Kh., Gilazov, T. Sh. (2014). Akhmed Midkhat $i$ tyurki Idel'-Urala [Ahmed Midhat and the Turks of Idel-Ural]. TATARICA. No. 1(2), pp. 62-80. (In Russian)

Bargan, Kh. (2016). Şemseddin Sami ve Idil-Ural tatarlari [Şemseddin Sami and Volga-Ural Tatars]. Türkiyat Mecmuas1, No. 26/1, pp. 51-60. (In Turkish)

Bargan, Kh. (2015). Yenileşme dönemi türk edebiyatı'nın İdil-Ural bölgesi tatar edebiyatı'na etkisi 
(1860-1917) [The Influence of Modern Turkish Literature on Volga-Ural Region Tatar Literature (1860-1917)]. Doktora Tezi, İstanbul. (In Turkish).

Batulla, R. (2013). Cengâver Alp'in Kahramanlıklarl [The Heroism of Cengâver Alp]. R. Batulla. Alyp batyr maжaralary. Tәгж. F. Kutlu. 178 p. Ankara, "Bəngy" nəshr. (In Turkish)

Dusun, H. (2001). Khaivannar turynda okiiatlor. Tekstlarda tatar tavyshlaryny evoliutsiiase Yzencholeklare [Fairy Tales about Animals (Animal Fairy Tales). Peculiarities of Evolution of Tatar Sounds in the Texts]. Basylyp chykmagan magistrlyk dissertatsiyase, Gazi universitety, Iжtimagyy fənnər instituty. (In Tatar)

Erish Soiturk, F. (2006). Mәжit Gafuri shigyrlare [Medjit Gafuri's Poems (Introduction-TextConcordance)]. Basylyp chykmagan magistrlyk dissertatsiyase, Ege universitety Iжtimagyy fənnər instituty. Izmir. (In Tatar)

Fildişi Çakl. Сөяк сапль пәке: Балалар хикәяләре жысентыгы (2013) [A Bone Pocket Knife: A Collection of Children's Stories]. Tәrж. F. Kutlu. 168 p. Ankara, "Bəngy" nəshr. (In Turkish)

Fəkhretdin, R. (1913). Okhmod Midkhat afande [Mr. Ahmad Midhat]. 144 p. Orenburg, "Vakyt" matbagasy. (In Tatar)

Garipov, M. (2016). Ebedi Aşk. Abdullah Tukay ve Zeytüne Mevlüdova Hikayesi [Eternal Love. The Story of Abdullah Tukay and Zeytine Mevludova]. Tatar Türkçesinden Türkiye Türkçesine Çev. Ç. Zaripova Çetin ve Hayati Yılmaz. 103 p. Ankara, Bengü Yayınlar1. (In Turkish)

Gatash, R. (2011). Na vechnom puti. Lirika raznykh let [On the Eternal Journey. Lyrical Poetry of Different Years]. Perevod na turetskiy Ch. Zarif-Chetin. Pp. 139149. Kazan. (In Turkish)

Gatash, R. (2011). Robagyylar bostany. Tatar hom torek tellarenda [To Be Paid]. Tәrж. Ch. Zarif-Chetin. Pp. 151-165. Kazan. (In Tatar, in Turkish)

Giyledgev, A. (2008). Жir kunaga. Tatars adabyty [A Handful of Earth. Tatar Literature]. Fatih Kutly tərжeməse, Kolonka basmalary, (1nche, 2nche basma 2008, 3nche basma 2011, 4nche basma 2013). Ankara. (In Tatar)

Ğiylecev, A. (2013). Cuma günü, akşam... [Friday, Evening...]. Тәгж. Ф. Кутлу. Анкара: “Бәнгү” нәшр. (In Turkish)

Ğ1ylecev, A. (2013). Bir Avuç Toprak [A Handful of Earth]. Tәrж. A. Akbash, F. Kutlu. 113 p. Ankara, "Bəngy" nəshr. (In Turkish)

Gelsun, A. (2006). Gaiaz Iskhakyinyy "Ike yoz eldan soł inkyyraz" hom "Zindan" asarlarendgege yzlek, (keresh - textual bibliographies kyrsatcheche) [Vocabulary of Ayaz İshaki's Two Stories "The Soonest Is in Two Centuries" and "Dungeon" (IntroductionText-Concordance)]. Basylyp chykmagan magistrlyk dissertatsiyase, Ege universitety, Iжtimagyy fənnər instituty. İzmir. (In Tatar)

Gultekin, M. (2010). Tatar akiyatlaren oyrəny [Research on Tatarstan Tales]. Basylyp chykmagan magistrlyk dissertatsiyase, Ege universitety, Iжtimagyy fənnər instituty. İzmir. (In Tatar)

İshaki, A. (2009). Hikayeler [Stories]. (Seçmeler) Tatar Türkçesinden Türkiye Türkçesine aktaran Çulpan Zaripova Çetin, Hayati Yılmaz. Muğla, Muğla Üniversitesi Yayınları, 181 p. (In Turkish)

Kap, Gulsemin (2004). Compassion (Transcription, Interpretation, Text Grammar, Dictionary), Unpublished Master's Thesis, Istanbul University, Institute of Social Sciences. Sakarya. (In Tatar)

Karakylych Aky, S. (2013). Galizskar Kamalnyн drama asorlorendo tel hom stil [Language and Style in the Dramatic Works of Galiaskar Kamal]. Kandidatlyk dissertatsiyase, Gazi universitety, Iжtimagyy fənnər instituty. Ankara. (In Tatar)

Kartaldgyk, V. (2008). Shorif Kamalnyн "Akcharlaklar" ham "Tan atkanda" asorlorendge tel enzencaleklare (keresh - textual bibliographies kyrsatkeche) [The Analysis of the Language in Sherif Kemal's Novels "Seagulls" and "At Dawn" (Introduction-Analysis-Text-Concordance)]. Basylyp chykmagan magistrlyk dissertatsiyase, Ege universitety, Іжtimagyy fənnər instituty. Izmir. (In Tatar)

Kazan tatarlary kupletlar (2013) [Kazan Tatar Couplets]. Ignats Kunos redaktsiyasendə. Tәrж. Mostafa S. Terkiya tele instituty. Syuzanna Kakk nəsherendə. Ankara. (In Tatar)

Kose, A. (2007). Rinat Mokhammadievney "Kenarui chitlek koshy" әsәrепең tәrж⿻етәse həm anda syyfatlarny ham figyllarney role, tatar-torek tel Yzenchenklekare [The Translation and the Role of Adjectives and Verbs in Rinat Muhammedin's Poem "Canary Is a Cage Bird". Peculiarities of the Tatar Turkish language]. Basylyp chykmagan magistrlyk dissertatsiyase, Chelal Bayar universitety, Iжtimagyy fənnor instituty. Manisa. (In Tatar)

Kuchuk Mehmetoglu, O. (2010). Musa Bigiyevnyy "Divani Khafiz" khikayasendage leksik terminnarga analiz [The Analysis of Vocabulary Terms in Musa Carullah Bigiyef's Story "Dîvân-1 Hâfız"]. Basylyp chykmagan magistrlyk dissertatsiyase, Gazi universitety, Iжtimagyy fənnər instituty. Ankara. (In Tatar)

Kurban, R. (2019). Mөkhəmmmət Мəhdievney “Tornalar toshkan жcirdə” agenda Kazan Tatar gorefgadətlore [Muhammad Magdeev's Story "The Cranes of Tamgaly". Kazan Tatar's Traditions]. Terek deniasy Tel həm ədəbiiat zhurnaly. No. 47, pp. 177-194. (In Tatar)

Kurban, R. (2016). Soi tormnyshny, soi gomerne, soi millatney doniiasyn [Life, Love, and Peace of Our Beloved Nation]. Tөрә. No. 36, 42. (In Tatar)

Kurban, R. (2014). Stalin davere hom korbannary [Stalin Era and Its Victims]. Pp. 90-98. Bez Ideldən, Uraldan . (In Tatar)

Kurban, R. (2014). Tatar ədəbiiatynda tarihi romannar [Historical Novels in Tatar Literature]. Bez Ideldən, Uraldan. Pp. 195-215. Istanbul. (In Tatar)

Kurban, R. (2014). Tatar adabiiatiny boek iməne Omir khan Eniki (1909 - 2000) [Amir Khan Eniki - the 
Great Faith of Tatar Literature (1909-2000)].Bez Ideldən, Uraldan. Pp. 140-151. (In Tatar)

Kurban, R. (2014). Tatar zyialysy Kaium Nasyiriny iska alganda [Tatar Intellectuals in Memory of Kayum Nasyri]. Bez Ideldən, Uraldan. Pp. 34 -54. Istanbul. (In Tatar)

Kurban, R. (2019). Tatar shigir donyasynył armastalmas kerəshchese Nə※ibə Safina [Naziba Safina, the Restless Fighter in the World of Poetry]. Өнжә Ватан. 27 May. Pp. 9-10. (In Tatar)

Kurban, R. (2014). Тииупун 150 elynda Tatars adabiiatiny filosofe shagyire Dardmand [150 Years since the Birth of Derdemend, a Poet-philosopher of Tatar Literature]. Bez Ideldделn, Uraldan. Pp. 65-80. (In Tatar)

Kurban, R. (2019). Тииупун 160 elda Dordməndney tormysh iuly ham iæçaty [Life and Work of Derdemend: On 160 Years of His Birth]. Terek denyasy Tarih, mədəniiat zhurnaly. No. 390, pp. 52-59. (In Tatar)

Kurban, R. (2014). Ylyепен 90 elda Dardmand [90 Years of Derdemend's Death]. Bez Ideldən, Uraldan. Pp. 81-90. (In Tatar)

Memish, S. (2012). Zolfat shigyr'larena analiz (keresh, tekstnyy bibliografik kyrsatkeche)/The Analysis of the poet Zolfet's poems (Introduction, Text, Concordance)]. Basylyp chykmagan magistrlyk dissertatsiyase, Ege universitety Iжtimagyy fənnər instituty. İzmir. (In Tatar)

Mirza, M. (2009). Adom balasy: shigyrlor. Tatarcha, ruscha, torekça, inglizche [A Human Child: Poems in Tatar, Russian, Turkish, English]. Тәрж. C. Zarif I F. Kutlu. 448 p. Kazan, Margarif. (In Tatar)

Muhammedi, R. (1993). Sirat kypere [Sirat Bridge]. Sultan Galiev, Тәрж. М. Онер. Төркия Бөтендөнья нәшрият фонды. No. 109, Istanbul. (In Tatar)

Muhammedi, R. (1996). Rossia demokratiiase [Russian Democracy]. Tәrж. M. Oner. Mestəkyl Basmalar. (In Tatar)

Oner, M. (1990). Gabdulla Tukai shigyrlare [Abdullah Tukay's Poems,] Basylyp chykmagan magistrlyk dissertatsiyase. Universitet Dokuz Eylul. Iжtimagyy fənnər instituty. İzmir. (In Tatar)

Oner, M. (2005). Tatar ikeyullyklary [Tatar Couplets]. Kum Saati Basmalara, İstanbul. (In Tatar)

Ozchoban, Yu. (2008). Ibrahim Salakhovnau̧ "Kolyma hikəyalare" həm "KYkçətau dalalarynda" romanlart (keresh - tekst - syzlek hom bibliografik kyrsatmo) [İbrahim Salahov's novels "Kolyma Stories" and "In the Steppes of Kukchetau" (Introduction-TextDictionary and Concordance)]. Basylyp chykmagan magistrlyk dissertatsiyase, İstanbul universitety, Iжtimagyy fənnər instituty, Balikesir. (In Tatar)

Ozkan, F. (1994). Gabdulla Tukai shigyrlare, tekstuny analizlau - təræçems ity [Gabdullah Tukay's Poems, Analysis-Text-Translation]. Turkiya mədəniyat fənni-tikshereny institutes nəshriyat. Ankara. (In Tatar)

Ozmen, O. (2006). Galimжçan Ibrahimovnyн "Kazakh kyzy" (keresh - textny, bibliografik kyrsatmose) [The Vocabulary of the Novel "Kazakh Daughter" by Galimжаn Ibrahimov (Introduction-Text-
Concordance)]. Basylyp chykmagan magistrlyk dissertatsiyase, Ege universitety Iжtimagyy fənnər instituty. Izmir. (In Tatar)

Polat, U. (2011). Sibgat Khəkim shigyrlare [Sibgat Hekim's Poems (Introduction-Text-Concordance)]. Basylyp chykmagan magistrlyk dissertatsiyase, Ege universitety Iжtimagyy fənnər instituty. Izmir. (In Tatar)

Salahov, İ. (2013). Kolyma khikayalare [Kolyma Prisoners]. Tatar intelligentsiyaseneң sergendəge istəlekləre. Тәгж. Y. Ozchoban. Kon'ia, Komen nəshriyaty (In Tatar)

Shahin, E. (1999). Tatar жyrlary жyyentygy (keresh-tekstnyy bibliografik kyrsatkeche)[A Collection of Tatar Songs (Introduction - Text - Translation Concordance)].Terkiya tele assotsiatsiyase nəshriyaty. Ankara. (In Tatar)

Shirin, H. (1998). Khasan Tufan shigyrlare, keresh syzlek [Hesen Tufan's Poems, IntroductionTextDictionary]. Basylyp chykmagan magistrlyk dissertatsiyase, Ege universitety Iжtimagyy fənnər instituty. Izmir. (In Tatar)

Sessiz Kurai (2013) [Silent Kuray]. Тәгж. A. Akbash, F. Kutlu. 190 p. Ankara, "Bəngy" nəshr. (In Turkish)

Topchu, H. (2009). Rezaetdin bin Fakhretdinneщ "Okhmad Midkhat afande" khezmatena analiz [The Analysis of Rizaeddin bin Fahreddin's Story "Ahmed Midhat Efendi']. Basylyp chykmagan magistrlyk dissertatsiyase, Gazi universitety, Іжtimagyy fənnər instituty. Ankara. (In Tatar)

Tukai, G. (2014). Kaitu: shigyr'lar [The Return: Poems]. Terek telenə tərж. B. Orukh Aslan, Y. Ozchoban. No. 117. Kon'ia. (In Tatar)

Tukay, G. (2016). Şiirler [Poems]. Tәrж. A. Akbash, F. Kutlu. 224 p. Ankara, "Bəngy" nəshr. (In Turkish).

Turhan, A. (2006). Tatar - torek tele. Razil Valiiev Tragediia [Tatar as a Turk Language. Rəzil Veliev Tragedy (Analysis-Text-Dictionary)]. Basylyp chykmagan magistrlyk dissertatsiyase, Firat universitety, Iжtimagyy fənnər instituty. Elazig. (In Tatar)

Türk Klasikleri Serisi [Turkish Classics Series]. Zambak Yayınları, İzmir. (In Turkish)

Uslu, A. (2004). "Tatar adabiatynda zamancha romannar hom akiiatlor (XIX qasyr ahyry XX gasyr bashi)" ["Modern Novels and Fairy Tales in Tatar Literature (end of the $19^{\text {th }}$ century - beginning of the $20^{\text {th }}$ century)". Basylyp chykmagan doctorlyk dissertatsiiase. (In Tatar)

Vasiyet (2012) [The Will]. Tәrж. F. Kutlu, h. OrsoyNadir, T. Arslan. 111 p. Istanbul, "Zambak" nəshr. (In Turkish)

Vəliev, R. (2007). Mavi Hüzün [Blue Sorrow]. R. Vəliev. Zəңgər sagysh. Tr. by F. Kutlu, h. Tashkyn. 144 p. Istanbul, "Da" nəshr. (In Turkish)

Zaidulla, R. (2016). Beyaz Hirkall Ihtiyar [An Old Man in a White Cardigan]. R.Zaidulla. Ak Yapanchaly kart. Tәrж. F. Kutlu. 111 p. Ankara, "BəngY" nəshr. (In Turkish) 
Zaripova-Çetin, Ç. A. (2016). Ibrahimov'un Eserlerinde Tatar, Başkurt ve Kazak Türklerinin Kültürel Değerleri [Cultural Values of Tatar, Bashkir and Kazakh Turks in Ibrahimov's Works]. 369 p. Ankara, Bengü Yayınları. (In Turkish)

Zaripova-Çetin, Ç. A. (2017). İbrahimov'un Kazak Klzı Adlı Romanında Kazak Türklerinin Iyiyecekİçecekleri ve Sofra Adabı [Good-drinks and Table Manners of Kazakh Turks in Ibrahimov's Novel "The Kazakh Girl']. Velikaya step'. II. Forum gumanitarnykh nauk. 2 kniga, pp. 235-244. Astana. (In Turkish)

Zaripova-Çetin, Ç. (2016). Kazan Tatar: Manilerinde Kadınların Talihsiz Kaderi [Kazan Tatar: The Unfortunate Fate of Women]. Atatürk Üniversitesi Türkiyat Araştırmaları Enstitüsü Dergisi (TAED) Journal of Turkish Research İnstitute. (57), pp. 1619-1636. (In Turkish)

Zaripova-Çetin, Ç. Ö. Beşirov, A. (2011). Şamov ve M. Mehdiyev'in Eserlerinde Tatar Türklerinin Milli Değerleri [M. Shamov and National Values of Tatar Turks in Mehdiyev's Works]. VI. Uluslararası Büyük Türk Dili Kurultayı Bildirileri (25-28 Eylül , 2011, Erzurum). Pp. 251-261. Ankara. (In Turkish)

Zaripova-Çetin, Ç. (2008). Şimalde Şark Gülleri Yetiştiren Şair Redif Gataş [Redif Gataş, the Poet Who Grew Oriental Roses]. Kardeş Kalemler, Sayı 22, Ekim Pp. 64-72. (In Turkish)

Zaripova-Çetin, Ç. (2009). Tatar Folklore ve Halk Edebiyatında Kayın A ̈gacı [The Beech Tree in Tatar Folk Literature]. Turkish Studies International Periodical for the Languages, Literature and History of Turkish or Turkic. Pp. 583-601. (In Turkish)

Zaripova-Çetin, C.. (2007). Tatar Halk Destanı "Idegey" de Geçiş Dönemleri [Transitional Periods in the Tatar Folk Epic "Idegey"]. Karadeniz Araştırmaları (Balkan, Kafkas, Doğu Avrupa ve Anadolu İncelemeleri) Dergisi. Kara M, N-15, Güz. Pp. 125-149. (In Turkish)
Zaripova-Çetin, Ç. (2011). Tatar Şairi Abdullah Tukay in Şiirlerinde Kuran Motifleri [Quranic Motifs in the Poems of the Tatar Poet Abdullah Tukay]. Kardeş Kalemler, Nisan, No. 52, pp. 40-45. (In Turkish)

Zaripova-Çetin, Ç. (2009). Tatar Türklerinin Gelenek ve Görenekleri [Traditions and Customs of Tatar Turks]. 160 p. Ankara, Karadeniz Dergisi Yayınları. (In Turkish)

Zaripova-Çetin Ç. (2019). Tatar Yazar Fevziye Beyremova'nın Edebi Kişiliği ve "Cengiz Aytmatov'un Tatar Annesi" Adll Kitabl Üzerine [On the Literary Personality of Tatar Writer Fevziye Beyremova and Her Book "The Tatar Mother of Genghis Aytmatov"]. Kardeş Kalemler, N- 149 (Mayıs). Pp. 64-72. (In Turkish)

Zaripova-Çetin, Ç. (2009). Tatar Yazarı Mirgazıyan Yunus'un Seyahatnamelerinde [Tatar Writer Mirgazıyan Yunus's Travelogues In Istanbul]. I. Uluslar arası Türk Edebiyatında İstanbul Sempozyumu (03-05 Nisan 2008). Bildirileri. Pp. 261-271. İstanbul. (In Turkish)

Zaripova-Çetin, Ç. (2007). Vatan Özlemi Konulu Tatar Manileri [Tatars Are Homesick]. ULuslararas1 Türk Medeniyetinde Sözlü Kültür Geleneği Sempozyum Bildirileri. Maniler. Pp. 212-220. İzmir, Sistem Serigrafi ve Matbaacilık. (In Turkish)

Zaripova-Çetin, Ç. (2017). Vefatının 80. Yılında Saygıyla Anıyoruz: Alimcan İbrahimov (1887-1938) [He died 80 Years Ago. This Year We Respectfully Commemorate: Galimjan Ibrahimov (1887-1938)]. Kardeş Kalemler, Şubat. Pp. 79-86. (In Turkish)

Zaripova-Çetin, Ç. (2018). Alimcan Ibrahimov un Almaçuar Adlı Eserinde Tatarların Milli Bayramı Sabantuy [Tatars' National Day of Sabantuy in Galimjan Ibrahimov's “Almaçuar”]. Uluslararası Türk Kültürü Sempozyumu ve Karma Türk Sanatları Sergisi. Makedonya-Üsküp. Pp. 58-66. Ankara. (In Turkish) 


\title{
ТӨРКИЯДӘ ТАТАР ӘДӘБИЯТЫ: ТАНЫЛУ ЮЛЛАРЫ ҺӘМ ӨЙРӘНЕЛУ ЮНӘЛЕШЛӘРЕ
}

\author{
Бирсел Оруж Аслан, \\ Балыкесир университеты, \\ Төркия, 10145, Балыкесир ш., Бигадич юлы, 17 нче йорт, \\ rezeda_raf@mail.ru.
}

Резеда Рафаил кызы Хәйретдинова, Казан федераль университеты, Россия, 420008, Казан ш., Кремль ур., 18 нче йорт, rezeda_raf@mail.ru.

Йусуф Озчобан,

Балыкесир университеты, Төркия, 10145, Балыкесир ш., Бигадич юлы, 17 нче йорт, rezeda_raf@mail.ru.

\begin{abstract}
Айсылу Хөсәен кызы Садекова, ТР ФАнең Г.Ибраһимов исем. Тел, әдәбият һәм сәнгать институты, Россия, 420008, Казан ш., К.Маркс урамы, 12 нче йорт, rezeda_raf@mail.ru.
\end{abstract}

\begin{abstract}
Мәкаләдә Төркиядә татар әдәбиятын таныту юлларына, аның өйрәнелү юнәлешләре һәм дәрәжәсенә күзәтү ясала. Гыйльми эзләнүләрнең фәнни проблемаларына, темаларына игътибар ителә. Бу рухи милли хәзинәне кардәш халыклар арасында танытуга һәм пропагандалауга зур өлеш керткән галимнәр, зыялылар катламы кебек мәсьәләләр ачыклана. Төрек әдәбият белемендә татар сүз сәнгатенә багышланган фәнни тикшеренүләрнең сыйфаты һәм саны турында мәгълүматлар да бирелә. Шул ук вакытта киләчәктә бу юнәлештә эзләнүләрнең перспективалары ачыкланып, Төркиядә татар әдәбиятының үсеш юллары билгеләнә.
\end{abstract}

Төп төшенчәләр: татар әдәбияты, Төркия, әдәбият белеме, әдәби бәйләнешләр, тәржемә, үсеш.

Татар hәм төрек халыкларының милли бердәйлекләренең төп күрсәткечләреннән берсе булган телләр якынлыгы, рух hәм дин уртаклыгы ике арадагы әдәби һәм мәдәни багланышларның тотрыклылыгын һәм дәвамчанлыгын тәэмин итәләр. Төрле ижтимагый-социаль һәм мәдәни шартларда яшәүләренә карамастан, бу ике милләт берберсенең мәдәнияте һәм сүз сәнгате белән кызыксына, ул гына түгел милли әдәбияттагы идея-эстетик кыйммәтләре белән бер-берсен баета. Ике арадагы тәүге бәйләнешләр 1552 елда Явыз Иван тарафыннан Казан ханлыгы алынганнан соң, Төркиягә качып, аннан кире кайткан халыкка hәм хаж кылган татар руханиларына нисбәт ителә [Барган, Гилазов, 2014, c. 73], [Bargan, 2015]. Төрек жәмгыятендә татарча укый-яза белү дәрәжәсе элек-электән югары була. Урта гасырларда Анадолу һәм Идел-Урал буе халыклары арасында рухи һәм мәдәни бәйләнешләр ныгый төшә. Анадолуда язылган китаплар Идел-Урал төбәгендә яратып укыла һәм, киресенчә, татар китаплары Анадолуда яратып кабул ителә һәм югары бәяләнә. XX гасыр башында Рәсәйдәге инкыйлаб вакытында революцион идеяләргә әверелгән татар зыялыларының бер катлам фәлсәфи һәм ижтимагый идеяләре Анодолуга үтеп керә.

Шәрык әдәбияты йогынтысында үскән татар сүз сәнгате, төрек әдәбияты кебек үк, XIX гасырның икенче яртысында Гареб мәдәниятенә йөз белән борыла һәм идея эчтәлеге һәм сәнгати эшләнеше ягыннан яңара башлый. Яңа татар прозасы формалашып, романнар һәм хикәяләр язылудан тыш, ирекле формадагы шигърият үрнәкләре дә ижат ителә. Мәгърифәтчелек чоры татар әдәбиятына төрек әдәбиятының йогынтысы шактый көчле була.

Билгеле булганча, Закир Рәмиев, Фәтих Кәрими, Галиәсгар Камал, Шәриф Камал кебек татар язучылары, татар тормышын яңарту өчен, 
төрек мәдәниятендәге һәм әдәбиятындагы казанышларны үзләштерү, дөньяви белемнәр алу максаты белән, Төркиягә киләләр, ягъни аларга төрек әдәбияты белән танышуның киң мөмкинлекләре ачыла. Энциклопедик гыйлемгә ия булган мәгърифәтче галим, әдип, тарихчы, язучы, казый Ризаэтдин Фәхретдин дә төрек әдәбиятын, аның күренекле шәхесләрен, фикер ияләрен жентекләп өйрәнә. Төркиянең мәшһүр әдибе, галим, философ, матбагачы, һәм жәмәгать эшлеклесе Әхмәт Мидхәт Әфәнде үлгәннән соң, аның хакында монографик хезмәт яза [Фәхретдин, 1913].

XIX гасыр ахыры - XX гасыр башларында аеруча көчәеп киткән бу процесс мәгълүм сәбәпләр аркасында совет чорында сүлпәнәеп кала. 1985 еллардагы үзгәртеп кору сәясәте кардәш-тугандаш халыклар арасында әдәбимәдәни бәйләнешләрнең яңадан торгызылуына һәм ныгуына юллар ача. 1989-1990 елларда төрки халыклар бәйсезлек яулап алалар һәм үз республикаларын төзиләр. Автоном республика булмыйча, Россиянең состав өлешен генә тәшкил иткән Татарстан да Төркия белән мәнәсәбәтләрен яңарта. Ике як та икътисади hәм мәдәни юнәлештәге хезмәттәшлеген тормышка ашыра башлый.

Шул унайдан Төркиядә татар теле һәм әдәбиятына карата кызыксыну арта hәм бу өлкәдә аерым тикшеренүләргә юл ачыла. Гыйльми эзләнүләрнең зур өлеше тарих һәм язучы ижаты белән синтезда тикшерелгән тел өлкәсенә карый. Әмма алар кулъязма хокукындагы фәнни эшләр калыбында язылу сәбәпле, киң аудиторияне колачлый алмыйча, гыйльми эшләр үзәгендә яисә университетлар архивында калалар. Шушы шартларны истә тотып, мәкаләдә Төркиядә татар әдәбиятының таралу һәм өйрәнелү дәрәжәсенә күзәтү ясау һәм аны бәяләү максат ителә, билгеле бер дәрәжәдә тел белеме өлкәсендәге хезмәтләргә дә игътибар ителә.

XXI гасыр башында төрекләрне татар халкының сүз сәнгате казанышлары белән таныштыру төрле формаларда булып, төрле катлам зыялылар тарафыннан алып барыла. Тәржемә башка халыкларның әдәби һәм мәдәни үсеше, рухи дәрәжәсе белән танышуда, теллөгать һәм әхлак алмашуда иң үтемле чараларның берсе булып тора. Ул телләре һәм диннәре уртак булмаган халыклар арасында да эчке һәм тышкы рухи элемтәләр урнаштыруга hәм бәйләнешләрне ныгытуга юллар ача. XX гасыр башында төрки-тугандаш халыклар арасында рухи һәм мәдәни багланышларны көчәйтү мәсьәләсе дәүләт югарылыгында алып барыла башлады. Татар әдәбияты классикларының, хәзерге заман язучыларының әсәрләренең төрекчәгә тәржемә ителеп, аерым китап рәвешендә дөнья күрүе шуның ачык чагылышы булып тора. 2005 еллардан башлап татар әдәбияты әсәрләре төрек теленә тәржемә ителеп, Төркиядә дөнья күрә башлады. Бу мәсьәлә әдәбият галиме $\Phi$. Сәйфулинаның А. Вәлиева белән берлектә язылган фәнни хезмәтендә бик жентекле тикшерелә [Сәйфулина, Вәлиева, 2017].

Шунысы куанычлы: татар язучыларының дөнья сүз хәзинәсендә урын алырлык әдәби әсәрләренең тирән эчтәлеге, югары сәнгати эшләнеше төрек ижат әһелләрен битараф калдырмый. Бу рухи байлыкны үз туган халкына житкеру максаты белән, төрек зыялыларының бер төркеме, татар телен махсус өйрәнеп, милли әдәбиятның матур үрнәкләрен төрек теленә тәржемә итү белән шөгыльләнә башлады: мәсәлән, М. Онәр, Ф. Кутлу һ. б.

Төрек Бөтендөнья тикшерену фонды Р. Мөхәммәдиевнең 1993 елда Мостафа Онер тарафыннан тәржемә ителгән «Сират күпере» әсәрен бастырып чыгарды [Мөхәммәдиев, 1993]. Китапта М. Солтангалиевнең тормышы hәм татар халкының бәйсезлеге өчен көрәше сурәтләнә. Моннан тыш М. Онер язучының 1990-1995 елларда парламент язмаларына нигезләнеп язылган «Рус демократиясе» дигән публицистик хезмәтен тәржемә итә [Мөхәммәдиев, 1996]. 1996 елда «Ituken publications» нәшрияты ярдәме белән нәшер ителгән китапта Р. Мөхәммәдиев 1989-1995 еллар аралыгында Россиядәге демократияләштерү процессын тасвирлап бирә.

Төрек укучысын татар әдәбияты белән таныштыруда башта кече эпик жанрларга мөрәжәгать ителә. Аларны туплаган «Vasiyet» («Васыять») жыентыгы 2005, 2006 hәм 2012 елларда «Замбак» нәшриятында басылды [Vasiyet, 2012]. Китапка тупланган әсәрләрне Фатих Кутлу, Хәмза Эрсой, Надир Тамәр Арсланнар татарчага тәржемә итүчеләр булып тора. Жыентыкка татар хикәяләренең иң матур үрнәкләре кертелгән: Ә. Еники («Әйтелмәгән васыять», «Матурлык»), Ш. Камал («Буранда», «Уяну»), Ф. Әмирхан («Бер харәбәдә», «Сәмигулла абзый»), Г. Ибраһимов («Табигать балалары»), М. Әмир («Мөстәкыйм карт йокысы»), Ф. Хөсни («Сөйләнмәгән хикәя»), М. Юныс («Безнең өй өянкеләр астында иде»). 
2007 елда Р. Вәлиев әсәрләре, Фатих Кутлу, Харун Тосун тарафыннан татарчалаштырылып, Төркиянең «Da» нәшриятында «Mavi hüzün» («Зәңгәр сагыш») исемендә дөнья күрде [Mavi Hüzün, 2007].

Тәржемәчеләр татар әдәбиятының барлык чорларына да мөрәжәгать итеп, төрек укучыларына милли сүз сәнгатендәге тематик киңлек, жанр төрлелеге һәм әдәби бәйләнеш хакында яңадан-яңа мәгълүмат бирәләр. Ч. Зарипова-Четин Х. Йылмаз белән берлектә, мәсәлән, ижатында гомумкешелек кыйммәтләрдән тыш ижтимагый-милли тематика кызыл жеп булып сузылган Г. Исхакый әсәрләрен [Ishaki, 2009], Ф. Кутлу белән хезмәттәшлектә татар шигъриятендә газәл, робагый жанрлары традицияләрен торгызган лирик шагыйрь Р. Гаташ поэзиясен [Гаташ, 2011. Робагыйлар...], [Гаташ, 2011. На вечном пути...] hәм М. Мирза [Мирза, 2009] әсәрләрен төрекчәгә тәржемә итә.

Ф. Сәйфулина Y3 мәкаләсендә, бу юнәлештәге эшчәнлеге югары бәяләнеп, Татарстан Язучылар берлеге әгъзасы буларак кабул ителгән тәржемәче һәм филолог Фатих Кутлуга киң туктала: «Ф. Кутлу тәржемәсендә „Fildişi Çakı (Tatar çocuk hikayeleri)““ („Балалар өчен язылган татар хикәяләре“) [Fildişi Çak1, 2013], „Sessiz Kuray“ („Тавышсыз курай“) [Sessiz Kuray, 2013] исемле повесть hәм хикәяләр жыентыгы „Бәнгү“ нәшриятында басылып чыкты. Аның тарафыннан Р. Батулла әкиятләре [Cengâver Alp'in Kahramanlıkları, 2013], балалар өчен „Altın Sincap“ („Алтын тиен“) [Altın Sincap, 2014] хикәяләр жынтыгы тәржемә ителеп төрек укучыларына барып иреште» [Сәйфулина, Вәлиева, 2017; 54 б.]. Соңгысында Н. Думави, А. Алиш, Г. Рәхим, Д. Аппакова, Л. Ихсанова, Ф. Вәлиев, Ф. Әмирхан h. б. язучыларның әсәрләре урын алган. Аның тырышлыгы белән Р. Зәйдулланың «Ак япанчалы карт» әсәре дә Төркия укучыларына барып ирешә [Зәйдулла, 2016]. Буыннан-буынга күчкән гомумкешелек кыйммәтләрне һәм традицияләрне саклаган татар язучыларының аерым хикәяләре Төркия Мәгариф министрлыгы тарафыннан мәктәп укучылары мәжбүри укырга тиешле дип расланган йөз китап арасында кертелә. Мәсәлән, Ә. Еникинең «Әйтелмәгән васыять» hәм «Матурлык» хикәяләре шундыйлардан.

Ф. Сәйфулина карашынча, Ф. Кутлуны татар әдәбиятын төрек теленә тәржемәче буларак таныткан хезмәтләреннән берсе -
Габдулла Тукай шигърияте. Моңа кадәр татар халык шагыйренең бу күләмдә төрек теленә әле тәржемә ителгәне булмый. Ф. Кутлу каләмдәше А. Акбаш бәй белән бу жаваплы эшне 10 ай дәвамында башкаралар. Милли шагыйребезнең 130 еллык юбилее уңаеннан 130 әсәре шагыйрь hәм язучы Р.Зәйдулла ярдәме белән сайлана [Сәйфулина, Вәлиева, 2017; 55 б.].

Фатих Кутлу, тәржемәчелек эшендә әдәби осталыгы һәм тәжрибәсе арта барган саен, катлаулырак әсәрләргә алына. Ул Төркиядә Аяз Гыйләжев ижатын танытуга да зур өлеш кертә. Тәржемәченең язучы белән беренче тапкыр танышуы аның әсәре аша булып, әлеге хакта ул китапның кереш өлешендә бәян итә. Аның тарафыннан А. Гыйләжевнең «Өч аршын жир» («Bir avuç toprak») [Ğıylecev A. Bir Avuç Toprak, 2008; 2011], «Жомга көн, кич белән...» («Cuma günü, akşam...») [Ğıylecev A. Cuma günü, akşam..., 2013] тәржемә ителә.

Мәгълүм булганча, бу әсәрләре А. Гыйлажевне сәнгать-әдәбият өлкәсендә бик зур дәрәжәле премия булып саналган «Габдулла Тукай исемендәге премия»гә лаек булган язучы итеп таныта. Аяз Гыйләжев - үзенең әсәрләре аша бәхетле тормыш тудырырга омтылган, И. В. Сталин чорының идеологиясенә каршы чыкканы өчен жәзага хөкем ителгән олы әдип. Авторның әсәрләрен татарчадан төрек теленә тәржемә итеп, Котлу аның изге теләген гамәлгә ашыра. 2012 елда Котлу Ауразия язучылар берлегендә «Өч аршин жир» өчен «Иң яхшы тәржемә ителгән роман» премиясенә лаек була. Шул рәвешле, Аяз Гыйләжев әсәрләре төрек аудиториясендә дә үз укучысын тапты һәм галимнәр тарафыннан фәнни әйләнешкә кертелде. Әлбәтт, әлеге юнәлештәге хәрәкәтнең башында Ф. Кутлуның тәржемә өлкәсендәге уңышлы эшчәнлеге тора. Нәкъ аның тәржемәләре аша татар язучысы әсәрләре төрекчә яңгыраш алды. Фатих Котлуның 2013 елда иң соңгы тәржемә әсәрләренең берсе хәзерге татар әдәбияты сайланма әсәрләрен туплаган «Тавышсыз курай» китабы басылып чыга [Sessiz Kuray, 2013].

«Ф. Кутлуның тәржемәче буларак игътибарын татар әдәбиятының төрле әдәбитарихи чорлары кызыксындыра, - дип языла мәкаләдә. - Ул тәржемә иткән әсәрләр арасында XX гасыр башы татар поэзиясе həм прозасы (Г. Тукай, Г. Ибраһимов, Ф. Әмирхан, Ш. Камал), Бөек Ватан сугышы еллары татар прозасы (А. Алиш), XX гасырның икенче яртысы прозасы һәм поэзиясе (Ф. Хөсни, 
А. Гыйләжев, Р. Вәлиев), бүгенге татар әдәбияты (Р. Батулла, Р. Зәйдулла) үрнәкләре дә бар» [Сәйфулина, Вәлиева, 2017; 55 б.].

2014 елның маенда «Кайту» исемендәге Г. Тукай шигырьләре жыентыгы, Бирсел Оруж Аслан һәм Йусуф Озчобан тарафыннан тәржемә ителеп, «Komen Publications» нәшриятында дөнья күрә [Тукай, 2014]. Тәржемәләр Тукайның вафатыннан соң төрле чор әдипләренең шагыйрьгә багышланган әсәрләрен туплаган «Мин Тукайга киләм» китабыннан алынган. Әлеге китапның оригиналь версиясен Гөлзада Бәйрәмова төзи һәм 1996 елда нәшер итә.

Күренекле әдипләрнең һәм шагыйрьләрнең ижат жимешләрен төрек теленә тәржемә итү әдәби жәмәгатьчелекне, китап сөючеләрне татар әдәбияты hәм рухи хәзинәсе белән танытуның бер юлы, беренче баскычы булып тора. Сонгы елларда төрек әдәбияты белемендә татар әдәбиятын өйрәнү юнәлешендә дә житди адымнар ясалды. Татар әдәбиятын тикшерүгә алынып, житди казанышларга ирешкән галимнәр катламы кызыклы тәэсир калдыра. Беренчедән шунысы куанычлы: татар әдәбиятының байлыгын тойган төрек галимнәре татар телен махсус өйрәнеп, милли әдәбиятның төрле чорларын һәм әдәби проблемаларын тикшерүгә алыналар.

Төркия Жөмһүрияте Истанбул университеты Гуманитар фәннәр институтындагы төрек теле һәм әдәбияты факультетының әдәбият галиме Хөсәен Барган әлеге юнәлештә уңышлы эшләп килә. Ул Татарстан Республикасына килеп, аның китапханәләрендә, архивларында төрле чыганакларны, әдәби материалларны жентекле өйрәнеп, бай материал туплый. Х.Барган башта татар әдәбиты хакында проблемалы мәкаләләр авторы буларак танылса, яңадан ул монографик хезмәт язуга алына. Галимнең фәнни эзләүнүләре нәтижәсендә «Жәдит чоры төрек әдәбиятының Идел-Урал өлкәсендәге татар әдәбиятына йогынтысы(1860-1917 еллар)» дип аталган фәнни хезмәте языла [Bargan, 2015]. Галим татар әдәбиятының 1860-1917 елларына мөрәжәгать итеп, милли сүз сәнгатенең яңарышына китергән социаль һәм мәдәни шартларын барлый. Ике гасыр чигендә рухи həм ижтимагый мәдәни бәйләнешләр контекстында төрек мәдәнияте hәм әдәбиятының татар әдәбиятына уңай йогынтысын ассызыклый. Шушы уңайдан татар фәлсәфәчеләре, ижтимагый фикер ияләре, дини рефрматорлары һәм шулай ук язучылардан һәм шагыйрьләрдән 3. Рәмиев, Ф. Кәрими, Ш. Камал, Г. Камал, Г. Тукай шәхесләренә туктала. Аларның тормыш юлларын һәм әдәби дөньяларын яңа мәгълүматлар белән баета.

«Габдулла Тукай шигырьләре (анализ тәржемәләр)» исемендәге китап Фатма Озкан тарафыннан 1994 елда бастырыла [Озкан, 1994]. Бу хезмәт Гази университетының Социаль фәннәр институтында Озканның докторлык диссертациясенә нигезләнеп эшләнә. Диссертация түбәндәге өлешләрдән тора: кереш өлеше, казан төркиләре, Габдулла Тукайның тормышы һәм әдәби әсәрләре. Беренче бүлектә Габдулла Тукай шигырьләренә эчтәлекле тасвирлама ясала, икенчесе шагыйрь поэзиясенә стиль һәм форма ягыннан анализ ясауга багышлана. Тукай һәм аның ижатына багышланган әлеге хезмәт иң тулы тикшеренүләрнең берсе булып тора. Тукай, фани дөньяда нибары 27 ел яшәвенә карамастан, татар шигьриятенең бөек остасы булып санала. Ул - татар төркиләренең күренекле шагыйре.

«Татар жырлары жыентыгы (кереш - текст - тәржемә - күрсәткеч)» дигән хезмәт Эрдал Шаһин тарафыннан 1999 елда басыла [Шаһин, 1999]. Китапның исемендәге фәнни проблемага язылган магистрлык диссертациясе нигезендә барлыкка килгән бу хезмәт 1997 елда Мәрмәрә университетының Төрек тикшеренүләре институтында нәшер итүгә әзерләнә. Төп мәгълүматны үз эченә алган кереш өч өлешкә бүленә. Текстларның тәржемәләре тикшеренүнең зур өлешен тәшкил итә. Транскрипцияләре һәм төрек теленә тәржемәләре бирелгән озын халык жырлары, кыска халык жырлары, литераль жырлар өч төрле исем астында тәкъдим ителә. Йомгаклау сүзлек белән беррәттән урнаштырыла.

Дөнья сүз сәнгатенең, шул исәптән татар әдәбиятының барлыкка килүендә нигез ролен үтәгән халык авыз ижаты, аның жәүһәрләре белән төрек укучыларын таныштыру юнәлешендә дә ныклы адымнар ясала. 2005 елда төрекчә грамоталылыкның (укый-яза белүнең. - acc. авторныкы) кыпчак төркеме буенча Үз хезмәтләре белән танылган Мостафа Онәрнең «Татар икеюллыклары» дигән фәнни хезмәте дөнья күрә [Онер, 2005]. Анда латинчага транскрипция ясалып һәм төрек теленә тәржемә ителгән 500 жыр урнаштырылган. Алар фольклорчы Н. Илбарисның «Кыска 
жырлар» (дүртьюллы колоритлы халык рифмалары) китабындагы 5630 жыр арасыннан сайлап алынган. Галимнең татар жырлары турындагы әлеге хезмәте бу өлкәдәге иң зур тикшеренүләрнең берсе булып санала. М. Онер хезмәтенең башында кыскача анализ ясалган икеюллык текстларны да урнаштыра. Китап ахырында транскрипция һәм тәржемә ясалган жырлар, аерым бүлекчә төсендә сүзлек бирелә.

С. Качалин тәржемә иткән казан татарлары жырлары беренче тапкыр 1914-1918 еллардагы сугыш вакытында әсирләрдән ишетелгән була hәм алар Игнаци Кунос тарафыннан язып алына [Казан татарлары куплетлары, 2013]. Бу жыентыкны Жужа Какук бастырып чыгаруга әзерләгән була. Өч телгә, ягъни татар, төрек, венгр телләренә тәржемә ителгән икеюллыкларны үз эченә алган әлеге кулъязма 212 биттән тора. Барлык материал 635 шигырьне үз эченә ала һәм язмаларның зур өлеше тикшеренүнең ахырына урнаштырылган.

XX-XXI гасыр чикләрендә мәгълүм сәбәпләр аркасында Төркиягә төрле катлам татар зыялылары күченеп китеп, анда татар диаспорасын барлыкка китерде. Алар арасында татар гыйльми академик мәктәбендә тәрбияләнгән татар әдәбияты, тел белеме һәм тарих галимнәре дә бар. Карс шәһәрендәге Кавказ университетының табигать-гуманитар фәннәре факультеты төрки телләр һәм әдәбиятлары кафедрасы доценты Чулпан Зарипова-Четин гыйльми эшчәнлегенең активлыгы белән аерылып тора. Аның фәнни эшчәнлегендә XX гасыр башы язучылары һәм совет чоры әдипләре өйрәнү объекты булып тора. Шул вакытта галимә игътибарын халык авыз ижатына, аеруча, милли гореф-гадәтләрне, традицияләрне тикшерүгә игътибарын көчәйтте. «Tatar Türklerinin Gelenek ve Görenekleri» дигән монографик хезмәте төрек укучыларын татар халкының йолалары һәм традицияләре белән таныштыра [ZaripovaÇetin, 2009]. «İbrahimov'un Eserlerinde Tatar, Başkurt ve Kazak Türklerinin Kültürel Değerleri» китабында XX гасыр башының күренекле язучысы Г. Ибраһимов әсәрләрендә татар, башкорт, казахларның рухи кыйммәтләренең чагылышы өйрәнелә [Zaripova-Çetin, 2009].

Ч. Зарипова-Четиннең гыйльми эшчәнлегенең аерым нәтижәләре фәнни журнал сәхифәләрендә урын ала. Алар арасында халык авыз сәнгате әсәрләрен [Zaripova-Çetin, 2007], татар халкының гореф-гадәтләрен, этнографик хосусиятләрен яктырткан мәкаләләреннән тыш
[Zaripova-Çetin, 2009], «Идегәй» дастанын [Zaripova-Çetin, 2007], шәркый традицияләр ноктасыннан Р. Гаташ шигьриятен [ZaripovaÇetin, 2008], М. Юныс юльязмаларын [Zaripova-Çetin, 2009] шәрехләгәннәре дә бар.

Мәгълүм булганча, Төркиянең һәр Югары мәктәбе социаль-гуманитар юнәлешләр буенча язылган хезмәтләрне бастыру өчен үз журналын чыгара. «Türklük Bilimi Araştırmaları Dergisi», «Türk Dünyası Dil ve Edebiyat Dergisi», «Kardaş Edebiyatlar Dergisi», «Milli Folklor Dergisi», «F1rat Üniversitesi Sosyal Bilimler Dergisi», «Türkoloji Araştırmaları Dergisi», «Atatürk Üniversitesi Türkiyat Araştırmaları Dergis», «TÜRKSOY Türk Dünyası Kültür, Sanat, Bilim, Haber ve Araştırma Dergisi», «Çukurova Üniversitesi Sosyal Bilimler Enstitüsü Dergisi», «İstanbul Üniversitesi Edebiyat Fakültesi Dergisi»» h.б.лар. Аларда татар теленә, әдәбиятына, фольклорына, тарихына караган күпсанлы теоретик, проблемалы һәм күзәтү мәкаләләре басыла. Р. Яруллина-Йылдырым, Э. Шаһин, А. Камалиева h.б.ларның хезмәтләре югарыда искә алынган журналларда басылган.

Р. Курбан да фәнни эшчәнлегенең активлыгы һәм нәтижәлелеге белән аерылып тора. Аның язмалары тематик яктан татар әдәбиятының төрле әдәби-тарихи чорларының күренекле язучыларын һәм шагыйрьләрен иңли: Каюм Насыйри [Курбан, 2014, Татар зыялысы...], Дәрдемәнд [Курбан, 2014, Тууының 150 елында...], Ә. Еники [Курбан, 2014, Татар әдәбиятының...], Ф. Яруллин [Курбан, 2017], М. Мәһдиев [Курбан, 2015], Н. Сафина [Курбан, 2019] һ.б.лар.

Төркия Жөмһүриятенең университетларында төрек филологиясе, фольклористикасы тармакларыннан галимнәр әзерләү мәсьәләсе бик житди куелган. Югары мәктәпләрнең чыгарылыш укучылары аны тәмамлаганда, диплом эшләре, магистратураны бетергәндә исә, магистрлык диссертациясен язалар. Гыйльми хезмәтләр үзәгенә тәкъдим ителгән барлык диссертацияләр һәм темалар аның вебсайтында хронологик тәртиптә бирелә. Фәнни эзләнү эшләренең темалары татар әдәбияты, тел һәм тюркология гыйлемнәренең төрле тармакларына, фольклористикага карый.

М. Онәрнең татар халкының бөек шагыйре Тукай шигъри дөньясын тикшергән «Габдулла Тукай шигырьләре» диссертациясе Докуз Эйлул университетының Гуманитар фәннәр институтында 1990 елда язып тәмамлана [Онәр, 1990] Кызганычка каршы, Диссертацияләр һәм 
диплом эшләре үзәге мәгълүматлар базасында әлеге диссертациягә кагылышлы бернинди мәгълүмат та сакланмаган.

Хәтидже Ширин Хәсән Туфанга (Текст сүзлек) багышланган диссертациясен 1998 елда тәмамлый [Ширин, 1998]. Татар әдәбиятының бөек шагыйрьләреннән берсе булган Х. Туфан үзенең туган иленә багышланган лирик шигырьләрен ижат итә. Шул әсәрләре аркасында ул, милләтчелектә һәм коммунистик революциягә каршы төркем оештыруда гаепләнеп, үлем жәзасына хөкем ителә, суд карары чыгу белән үк, ул сөргенгә жибәрелә. Ширин үзенең диссертациясен өч өлешкә бүлә. Кереш өлешендә X. Туфанның тормыш юлы, шагыйрьнең ижтимагый һәм әдәби түгәрәкләр белән бәйләнеше турында белешмә бирелә, төп игьтибарны исә диссертант шагыйрь поэтик теленең үзенчәлегенә юнәлтә. Диссертациянең икенче өлешендә автор Туфанның «Сайланма әсәрләре»нең 1 hәм 2 томлыкларының төрек теленә транскрипциясен бирә. Ахыргы бүлектә тексттан сайлап алынган сүзлек һәм йомгаклау өлеше урын ала.

2000 елда Гөксел Акча тарафыннан «Тылсымлы әкиятләр (тылсымлы хәлләр) текстларындагы татар теленең морфологик яктан тасвирламасын бәяләү» дигән темага дүрт бүлектән торган (кереш, анализ, текст һəм тәржемә) магистрлык диссертациясе яклана [Акча, 2000]. Әкиятләрнең төрле төрләре турындагы гомуми мәгълүмат кереш өлешендә бәян ителә. Тылсымлы әкиятләрнең морфологик тасвирламасы анализ бүлегендә урын ала. Текст бүлегендә мисаллар, ә тәржемә бүлегендә аларның төрек теленә тәржемәсе бирелә. Тылсымлы әкият текстларының унжиде төрле тибы барлыгы әйтелә һәм татар әкиятләре үрнәкләре белән дәлилләнә. Хезмәттәге барлык текстларны төрек теленә Акча шәхсән үзе тәржемә иткән.

«Хайваннар турындагы әкиятләр текстларында татар авазлары эволюциясе үзенчәлекләре» дигән темага хезмәтне Хури Дурсун 2001 елда яза [Дурсун, 2001]. Әкият текстлары нигезендә татар-төрек авазлары үзенчәлекләрен ачыклау тикшеренүнең төп максаты булып тора. Диссертация дүрт өлештән тора: кереш, анализ, текстлар, тәржемә. Кереш өлешеннән соң килә торган анализ бүлегендә авазлар тасвирламасын ачыклау өчен китерелгән мисаллар урын ала, алар борынгы hәм хәзерге төрек телләре белән тәңгәл куеп карала. Төп өлештә 33 әкият текстына транскрипция ясала. Тәржемә бүлегендә исә әлеге 33 әкиятнең төрек теленә тәржемәсе бирелә.

2004 елда фәннәр докторы профессор Явуз Акпынар житәкчелегендә Айшән Услу «Татар әдәбиятында заманча романнар һәм әкиятләр (XIX гасыр ахыры - XX гасыр башы)» дигән темага докторлык диссертациясен язып тәмамлый [Услу, 2004]. Анда татар әдәбиятының «алтын чоры» турында мәгълүмат бирелә, бу дәвердә милли сүз сәнгатенең торышы, яңарышның социаль һәм мәдәни шартлары төрки-татар багланышлары контекстында бәян ителә. Әлеге хезмәт бу әсәрләрнең ижтимагый һәм милли әһәмиятенә басым ясап, аларны укырга теләүчеләрдә кызыксыну уята.

«Шәфкать» романы (транскрипция тәржемә - текст грамматикасы - сүзлек) дигән темага язылган диссертацион тикшеренү эше 2004 елда Гөлсемин Кап тарафыннан языла [Кап, 2004]. Хәзерге татар әдәби теле турында киң мәгълүмат бирә торган әсәрнең авторы Мәдинә Маликова. Аңлашыла булса кирәк, эчтәлек белән форманың диалектик бәйләнеше төрек галимнәренә романның идеясе, күтәрелгән проблемалар һәм аларның сәнгати хәл ителеше турында да мәгълүмат бирә. Тикшерену өч өлештән тора: тел үзенчәлекләрен өйрәнү, транскрипция һәм текстның төрек теленә тәржемәсе. Диссертация ахырында сүзлек бирелә. Тикшеренү аваз төзелешен һəм морфологик үзенчәлекләрне өйрәнүгә багышлана. Текстның транскрипциясе һәм төрек теленә тәржемәсе параллель рәвештә бирелә. Диссертация ахырында кириллицага нигезләнеп язылган төп текст нөсхәсен табарга мөмкин.

2006 елда Сельда Арслан «Рәмзи Вәлиев трагедия (анализ - текст - сүзлек)» дигән темага диссертация язып тәмамлый [Арслан, 2006]. Төрек теленә тәржемә ителгән «Трагедия» романында, татар төрекләре кичергән кыенлыкларга карамастан, аларның милләтпәрвәрләр тарафыннан яклау табулары турында сүз бара. Гомумән алганда, әсәр Казан төрекләренең советлар чорында кичергән рухи фажигасен тасвирлый. Романда татар зыялыларының, бигрәк тә дворян гаиләләренең Сталин тарафыннан эзәрлекләнүләргә дучар ителүе күрсәтелә. Хезмәтнең темасы - татар фонетикасы, морфологиясе һәм сүз ясалышы. Диссертация ахырында текст транскрипциясе, шулай ук сүзлек тә бирелгән. 
2006 елда Озлем Озмен «Галимжан Ибраһимовның „Казакъ кызы“ романының лексикасы (кереш - текст - күрсәткеч)» дигән темага диссертация яклый [Озмен, 2006]. Өйрәнү-тикшеренү объекты итеп исеме төрек дөньясы мәгарифе тарихында танылган һәм Идел-Урал төбәгенең билгеле язучысы Галимжан Ибраһимовның «Казакъ кызы» романы алына. Әдип бөтен төрек дөньясында, иң беренче чиратта, популяр автор буларак билгеле. Тикшерену предметы булып Галимжан Ибраһимов романының теле тора. «Казакъ кызы» әсәреннән алынган текстлар гарәп алфавитында язылган. Диссертация дүрт өлештән торып, беренче өлештә XX гасыр башы татар әдәбиятына тарихи һәм мәдәни характеристика, шулай ук авторның тормыш юлы һәм ижаты турында белешмә бирелә, язучының киңкырлы гыйльми эшчәнлеге белән бәйле хезмәтләре белән танышырга мөмкин. Икенче өлешне романнан алынган татар һәм төрек телләрендәге текстлар тәшкил итә. Өченче өлештә «Каталог» дигән исем астында бирелгән сүзлек, махсус тупланган төп сүзләр hәм еш кулланылган сүзләр исемлеге урын алган. Йомгаклауда тикшеренүдә ирешелгән фәнни казанышларга гомумиләштерүләр һәм нәтижәләр ясала.

«Гаяз Исхакыйның „Ике йөз елдан соң инкыйраз“ һәм „Зиндан“" исемле ике әсәренең лексикасы (текст - кереш - күрсәткеч)» (Төркия, 2006) дигән диссертацион эзләнүләрнең авторы - Ариф Гөлсун [Гөлсун, 2006]. Идел-Урал милли-азатлык хәрәкәтенең әйдәп баручысы, журналист һәм язучы Гаяз Исхакый бөтен гомерен татар халкының бәхете өчен көрәшкә багышлый, барлык тормыш авырлыкларын үз жилкәсендә татый hәм ү3 идеалыннан ваз кичми. Хезмәтнең тикшеру объекты булып торган әсәрләр язучының 1910 елга кадәрге ижатына карый. Аларның лексикасын ачыклаганда, автор ике повестьның идея эчтәлегенә һәм эчке төзелешенә дә игътибар итә. Диссертация биш өлештән тора. Керештә Гаяз Исхакыйның гомер юлы, тормышыннан алынган аерым вакыйгалар турында сүз бара. Төп өлештә ике повестьның латиницадагы варианты hәм төрек теленә тәржемәләре бирелә, аларның язылу тарихлары сөйләнелә. Хезмәтнең алдагы өлешендә әсәрләр лексикасының күрсәткечле сүзлеген табарга мөмкин. Тикшеренүнең белешмә бүлеген Гөлсун дүрт өлешкә бүлеп карый: ялгызлык исемнәр, еш кулланылыштагы сүзләр, цитаталар, өстәмә күрсәткеч. Диссертациянең йомгаклау өлешендә күзәтүләргә нәтижәләр ясала.

2006 елда Фатма Эриш Сойтурк «Мәжит Гафури ижаты (кереш - текст - күрсәткеч)» дигән темага диссертация яза [Эриш Сойтурк, 2006]. Әлеге хезмәт, 1880 елда Уфа шәһәрендә туып, XX гасырның башында ижат итә башлаган татар hәм башкорт халкының танылган шагыйрьләреннән берсе Мәжит Гафурига, аның әдәби шәхесен һәм язу стиле үзенчәлекләрен өйрәнүгә багышлана. Габдулла Тукайның дәвамчысы булган Мәжит Гафури үзенең күркәм шигырьләрендә татар hәм башкорт әдәбиятының классик һәм халык шигърияте үрнәкләрен тудыра. Тикшеренү 1909-1918 еллар аралыгында гарәп хәрефләре белән язылган Гафуриның 6 шигырьләр жыентыгына нигезләнеп башкарыла. Диссертация дүрт өлештән тора. Кереш өлешендә XX гасыр башы татар әдәбиятының үзенчәлекләре hәм шагыйрьнең бу чорда тоткан урыны турында бәян ителә. Диссертациянең төп өлеше гарәп алфавитында язылган, транскрипцияләре һәм тәржемәләре бирелгән həм төп нөсхәгә туры килә торган (аутентик) шигырь текстларын үз эченә ала. Күрсәткеч өлешендә сүзлек, ялгызлык исемнәр, цитаталар hәм еш кулланылган сүзләр исемлеге тәкъдим ителгән.

Ринат Мөхәммәдиевнең "Кенәри - читлек кошы” романында сыйфатларның һәм фигыльләрнең роле һәм тәржемәсе, татар-төрек телен өйрәнүнең үзенчәлекләре" дигән хезмәтне Әйхан Косе 2007 елда яза [Косе, 2007]. Әдәбият белеме һәм тел гыйлеме синтезында эшләнгән эзләнү эшендә романның теле тикшерелә, бигрәк тә сыйфатлар һәм фигыльләрне өйрәнүгә игътибар ителә. Бу тикшеренүдә, күләме зур булу аркасында, моңа кадәр тәржемә ителмәгән әсәрнең төрек теленә тәржемәсе бирелә. Диссертация ике өлештән тора: беренче өлештә, автор турында белешмә, казан төрки татарларының әдәбияты турында гомуми мәгълүмат урнаштырыла, ә аннан татар тел белеме турында сүз алып барылып, әдәби әсәрнең теле анализлана, андагы сыйфат һәм фигыльләр аерып алынып әтрафлы тикшерелә. Әдәби әсәрнең тәржемәсе тикшеренүнең икенче өлешендә бирелә. Роман утыз тугыз бүлектән тора. Диссертацион хезмәттә композицион өлешләр аерым урын алып торалар. 
2008 елда Ведат Карталжык «Шәриф Камалның „Акчарлаклар“ һәм „Таң атканда“ әсәрләренең телен тикшерү (кереш - анализ текст - күрсәткеч)» дигән темага кандидатлык диссертациясен яклый [Карталжык, 2008]. Керештә XIX-XX йөз чикләре татар әдәбиятының торышына күзәтү ясала, шулай ук монда Шәриф Камалның тормыш һәм ижат юлына да урын бирелә. Беренче бүлектә тикшеренү объекты булган текстларның төрле үзенчәлекләре тикшерелә, ә икенчесендә әсәрләргә жентекле грамматик анализ ясала. Диссертациянең өченче өлешендә язучы әсәрләренең төрек теленә тәржемәсе тәкъдим ителә. Дүрт өлештән торган алдагы бүлектә аерым сүзләр, кулланылган исемнәр, цитаталар исемлеге һәм аеруча еш кулланылган сүзләр күрсәткече белән танышырга мөмкин. Йомгаклауда күзәтүләргә нәтижәләр грамматик берәмлекләрнең һәм әсәрләр теленең статистик мәгълүматлары белән баетылып бирелә.

2008 елда Йусуф Озчобан Ибраһим Сәлаховның «Колыма хикәяләре» hәм «Күкчәтау далаларында» (кереш - текст сүзлек - күрсәткеч) романнарын тикшерүгә багышланган диссертациясен тәмамлый [Озчобан, 2008]. Ибраһим Сәлахов - ХХ йөздә ижат иткән күренекле татар язучысы. Ул Сталин шәхес культы елларында нахакка хөкем ителгән татар зыялыларының берсе. Тикшеренүдә И. Сәлаховны үзенчәлекле язучы буларак таныткан «Күкчәтау далаларында» həм «Колыма хикәяләре» романнары анализлана. Бу ике әсәрне төрекчәгә тәржемә иткәндә, диссертант язучының стилен дә, әсәр телен дә саклап калырга тырышкан. Хезмәт ике романның да жентекле анализын үз эченә ала.

Хәерниса Топчуның магистрлык диссертациясе «Ризаэтдин бин Фәхретдиннең „Әхмәт Мидхәт Әфәнде“ хезмәтен анализлау» дип атала [Топчу, 2009]. Тикшеренү эше кереш, текст һәм анализ өлешләреннән тора. Әсәрнең төрек теленә тәржемәсе төп өлештә урын ала. Төркиядә авторның танылмаган булуын искә алып, тикшеренүче аның тормыш сукмаклары hәм әдәби эшчәнлеге турындагы жентекле мәгълүматны аналитик өлештә бирә. Текстларның кыскача йомгагы (резюме) анализ өлешенә кертелгән. Биредә шулай ук әсәрнең теле һәм стиле дә тикшерелә. Хезмәтнең стркутурасын анализ, йомгаклау hәм кулланылган әдәбият исемлеге билгели.

Татар халык авыз ижаты буенча «Татар әкиятләрен тикшерү» дигән темага Мостафа
Гөлтекин тарафыннан тагын бер тикшерену эше башкарыла [Гөлтекин, 2010]. Хезмәттә татар әкиятләренең форма, төзелеш, эчтәлек hәм вазифа проблемалары өйрәнелә. Беренче бүлектә тикшеренүче татарлар һәм әкиятләр турында гомуми белешмә урнаштырып, татар әкиятләренең төрек дөньясында тоткан урынына басым ясый; диссертациянең икенче өлешендә бу жанрда сурәтләнгән вакыйгалар характеры турында белешмә урнаштырыла; өченче өлештә төзелеш мотивы тикшерелә. Дүртенчесендә татар әкиятләрендә кулланыла торган күренешләр тасвирлана. Йомгак, кулланылган әдәбият һәм алфавит тәртибендә бирелгән күрсәткеч текстларның төрек теленә тәржемәсе белән бергә хезмәтнең ахыргы өлешендә урнаштырыла.

2010 елда Өмәр Кучук Мәхмәтоглы Муса Яруллаһ Бигиевнең «Диваны Хафиз» әсәрендәге лексик терминнарны тикшеру” дип исемләнгән тикшеренү эшен төгәлли [Кучук Мәхмәтоглы, 2010]. Гыйльми хезмәттә «Диваны Хафиз» әсәрендә Бигиев тарафыннан кулланылган лексика үзенчәлекләре тикшерү предметын билгели. Күзәтүләр Казан төрки әдәбияты белән Госман төрки әдәбияты арасында охшашлык барлыгын ачык күрсәтә. Шуна күрә Казанда басылып чыккан әлеге әсәр Истанбулда да укылган һәм югары бәягә лаек булган. Диссертациянең кереш өлешендә Муса Яруллаһ һәм аның ижаты турында гомуми мәгьлүмат бирелә. Хезмәтнең беренче өлешендә тексттагы гарәп әлифбасы латиница белән алмаштырыла. Диссертациянең икенче өлешендә татарча язылган текст төрек теленә тәржемә ителә. Өченче бүлектә «Диваны Хафиз» китабының лексикасы госман төрек теле лексикасы белән чагыштырма планда карала.

Ширин Аксой - «Татар авторы Гариф Ахуновның „Тормыш юлы“ романының телен тикшеру (кереш - текст - күрсәткеч)» дигән диссертациянең авторы [Аксой, 2011]. Күренекле язучы һәм дәүләт эшлеклесе Гариф Ахунов, халык бәхете өчен хезмәт итеп, укучыларны изге эшләргә рухландыра. Роман үзәгендә сурәтләнгән идеаль ир-ат явызлык һәм гаделсезлек белән көрәшә. Тикшеренү эшен Аксой дүрт төп өлешкә бүлә: кереш, текст, күрсәткеч hәм йомгак. Диссертациядә авторның әдәби шәхес булуына басым ясалып, аның тормыш юлы тасвирлана һәм шушы уңайдан XX гасыр татар әдәбиятына гомуми күзәтү ясала. Алга таба текстның теле тикшерелә. 
Әсәрнең транскрипциясе һәм төрек теленә тәржемәсе төп өлештә бирелә. Тексттагы һәр сүзне алфавит тәртибендә бирелгән күрсәткечтә табарга мөмкин. Йомгаклау өлешендә роман тел-стиль үзенчәлекләрен күзәтүләргә нәтижәләр урнаштырылган.

«Сибгать Хәким шигырьләре (кереш - текст - күрсәткеч)» фәнни-тикшеренү эшен Улку Полат 2011 елда яза [Полат, 2011]. Әлеге зур күләмле хезмәт 1449 биттән тора. Керештә шагыйрь турындагы мәгълүматтан соң, 1905 елдагы хәлләр һәм татар әдәбиятының торышы турында бәян ителә. Алга таба С.Хәким биографиясе hәм ул ижат иткән чордагы әдәби юнәлеш белән таныштырыла. Шунда ук шигырьләр каталогы һәм исемлеге бирелә. Тикшеренүнең төп өлешендә татарча аутентик, ягъни төп нөсхәгә туры килә торган шигырьләрләрдән алынган мисаллар һәм аларның төрек теленә тәржемәсе урнаштырыла. Күрсәткеч өлешендә шигырьләрдә кулланылган сүзләрнең аңлатмасы һәм аларның урнашуы турында жентекле мәгълүмат бирелә. Диссертация йомгак өлеше белән тәмамлана.

«Шагыйрь Зөлфәт шигырьләренә анализ (кереш - текст - күрсәткеч)» хезмәтенең авторы - Сәхәр Мемиш [Мемиш, 2012]. Диссертация биш өлешкә бүленгән: кереш, төп өлеш, глоссарий, йомгак һәм кулланылган әдәбият. Төп өлеш белән үрелеп барган кереш Зөлфәтнең тормышы һәм аның шигъриятенең теле һəм тематикасы турындагы мәгълүматны Yз эченә ала. Эзләнү авторы Зөлфәтнең «Ике урман арасы» дигән жыентыгыннан алынган шигырьләрен тәкъдим итә. Диссертация ахырында шигырьләрнең төрек теленә тәржемәләре урнаштырылган. Глоссарий шагыйрь поэтик телендәге сүзләрне үз эченә ала.

2013 елда Серафим Каракылыч Агы «Галиәсгар Камалның театр әсәрләрендә тел һәм стиль» темасына докторлык диссертациясе яклый [Каракылыч Агы, 2013]. Әлеге тикшеренү эше татар әдәбиятындагы зур дәрәжәле драматург, татар театрына нигез салучы Галиәсгар Камалны шәхес буларак ачуны һәм аның әсәрләренең тел һәм стиль тасвирламаларын тикшерүне максат итә. Диссертация кереш, Галиәсгар Камалның тормышы һәм ижаты, анализ, йомгак, кулланылган әдәбият, сүзлек, текстларны үз эченә алган кушымталардан тора. Кереш өлешендә театр турында гомуми белешмә бирелгәннән соң, автор тәрбияләнгән әдәби һәм мәдәни мохит тасвирлана. Галиәсгар Камалның тормыш һәм ижат юлы баштагы өлештә бирелә. Диссертациянең икенче өлешендә автор пьесаларындагы тел һәм стиль үзенчәлекләренә анализ ясала: дөрес язылыш үзенчәлекләре, сүзләрне сайлап алу, жөмләләр төзү алымнары өйрәнелә. Югарыда китерелгән һәр бүлекчәдә автор тарафыннан сүзләрнең кулланылыш үзенчәлекләре һәм аерымлыкларына игътибар юнәлтелә. Йомгаклауда текстларны аңлау мөмкинлеген киңәйткән анализ нәтижәләре бирелә, шифр белән тамгаланган текстлар һәм аларның тәржемәләре төп өлештә урын ала, ә диссертация ахырында сүзлек бар. Төрек теленә тәржемә ителгән текстлар Г. Камалның егермеләп драмасыннан алынган.

«Татар авторы Тәлгат Галиуллинның „Тәүбә“ романының телен анализлау (кереш текст - күрсәткеч)» дигән хезмәт Эрман Әйдоганнар тарафыннан 2013 елда языла [Әйдоганнар, 2013]. Тикшеренү эше татар язучысы hәм публицисты Т. Галиуллинның 1997 елда басылган «Тәүбә» романына нигезләнеп башкарыла. Фәнни эшнең төзелешен кереш, текст (төп өлеш) һәм сүзлек билгели. Кереш Т. Галиуллинны әдәби шәхес буларак ачкан белешмәне, аның тормышы һәм әдәби әсәрләренә кагылышлы гомуми

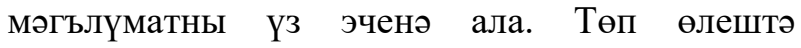
романның латинчага күчерелгән һәм төрек теленә тәржемә ителгән текстлары урнаштырылган. Роман теленең грамматик күрсәткечләре аерым структур катлам буларак тәкъдим ителгән.

Тикшеренүләргә нәтижә ясап, шуларны әйтергә мөмкин: көнбатыш әдәбиятларының басымы, таралыш даирәсе көчле булуга карамастан, Төркиядә татар нәфис сәнгате белән кызыксыну арта. Төрек укучыларын, әдәби жәмәгатьчелеген татар әдәбиятының кыйммәтле сәхифәләреннән булган Г. Тукай, Ф. Әмирхан, Г. Ибраһимов, Ш. Камал, Ә. Еники кебек татар классиклары, шулай ук хәзерге чор язучылары Р. Гаташ, Р. Вәлиев, М. Галиев, Г. Гыйльманов, Р. Зәйдулла һәм башкалар ижаты кызыксындыра. Тәржемәләр арасында XX гасыр кешесенең катлаулы рухи дөньясын, милли сыйфатларын, авыл кешесенең бай, кызганыча каршы югалып бара торган рухи һәм мәдәни байлыгын тасвирлаган A. Гыйләжевнең «Өч аршын жир» («Bir avuç toprak») həм «Жомга көн, кич белән...» («Cuma günü, akşam...») әсәрләре аеруча үзенчәлекле урын тота. 
Төркиядә татар әдәбияты, аның бай тарихы, милли үзенчәлекләре белән таныштыруда, бу кыйммәтле мирасны пропагандалауда төрле катлам әдәбият һәм тел галимнәре, тюркологлар тарафыннан алып барылган тикшеренүләр һәм эзләнүләр дә мөмтаз урын алып тора. Язма әдәбиятның нигезендә яткан татар халык авыз ижаты, аның жанрлары һәм хосусиятләре белән төрек әдәби жәмәгатьчелеген таныштыру юнәлешендә ныклы адымнар ясала. Бу уңайдан аеруча жырлар, әкиятләр, дастанннар, аларның жанрлар системасын ачыклауга багышланган кызыклы күзәтүләр бар. Шулай ук язучылар тел-стиль үзенчәлекләре өйрәнелгән гыйльми хезмәтләрдә татар әдәбияты, аның аерым әдәби-тарихи чорлары, күренекле әдипләрнең тормыш юлы, ижат хосусиятләре, образлысурәтләү үзенчәлекләре белән таныштырыла.

Киләчәктә Төркиядә Кәрим Тинчурин, Фатих Кәрим, Фатих Әмирхан, Мөхәммәт Мәһдиев, Кави Нәжми, Сажидә Сөләйманова кебек XX йөзнең танылган авторларының әсәрләрен, шулай ук дөнья әдәбиятының башка классикларын укуны дәвам итәрләр, бу тармакта гыйльми эзләнүләрнең тематикасы, офыгы киңәер дип ышанасы килә. һәм алар, үз нәүбәтендә, ике кардәш-тугандаш халыклар арасындагы рухи, әдәби-мәдәни һәм гыйльми бәйләнешне көчәйтүгә хезмәт итәрләр дигән ышанычны ныгыта.

\section{Әдәбият}

Аксой ШU. Татар авторы Гариф Ахуновның «Тормыш юлы» романын анализлау (кереш текстның библиографик күрсәткече). Басылып чыкмаган магистрлык диссертациясе, Эге университеты, Ижтимагый фәннәр институты. Измир, 2011. (төрек телендә).

Акча $\quad$ Г. Тылсымлы әкиятләр (Тылсымлы хикәяләр) Текстларда татар морфологик характеристикаларны бәяләү. Басылып чыкмаган магистрлык диссертациясе, Гази университеты, Ижтимагый фәннәр институты. Әнкара, 2000. (төрек телендә).

Арслан С. Рәмзи Вәлиев - трагедия (анализ текст - сүзлек). Басылып чыкмаган татар-төрек диссертациясе, 2006. (төрек телендә).

Әйдоганнар Э. Татар авторы Тәлгат Галиуллинның «Тәүбә» романын анализлау (кереш - текстның библиографик күрсәткече). Басылмаган магистрлык диссертациясе, Эге университеты, Ижтимагый фәннәр институты. Измир, 2013. (төрек телендә).

Барган Х., Гилазов Т. Ш. Ахмед Мидхат и тюрки Идель-Урала // TATARICA. 2014. № 1 (2). С. 62-80.
Батулла P. Cengâver Alp'in Kahramanlıkları. P. Батулла. Алып батыр мажаралары / тәрж. Ф. Кутлу. Анкара: «Бәнгү» нәшр., 2013. 178 б. (төрек телендә).

Вәлиев P. Mavi Hüzün / Р.Вәлиев. Зәңгәр сагыш / тәрж. Ф. Кутлу, h. Ташкын. Истанбул: «Да»нәшр., 2007. 144 б. (төрек телендә).

Гаташ Р. На вечном пути. Лирика разных лет / Перевод на турецкий Ч. Зариф-Четин. Казань, 2011. С. 139-149. (төрек телендә).

Гаташ Р. Робагыйлар бостаны. Татар һәм төрек телләрендә / тәрж. Ч. Зариф-Четин. Казан, 2011. С. $151-165 \mathrm{c}$

Гөлсун А. Гаяз Исхакыйның «Ике йөз елдан соң инкыйраз» hәм «Зиндан" әсәрләрендәге сүзлек, (кереш - текстның библиографик күрсәткече). Басылып чыкмаган магистрлык диссертациясе, Эге университеты, Ижтимагый фәннәр институты. Измир, 2006. (төрек телендә).

Гултекин M. Татар әкиятләрен өйрәнү. Кандидатлык диссертациясе, Эге университеты, Ижтимагый фәннәр институты. Измир, 2010. (төрек телендә).

Гыйләжеве А. Жир кунагы. Татар әдәбияты: Фатих Кутлы тәржемәсе, Колонка басмалары, Әнкара. (1 нче, 2 нче басма - 2008, 3 нче басма 2011, 4 нче басма - 2013). (төрек телендә).

Дусун $X$. Хайваннар турында әкиятләр. Текстларда татар тавышларының эволюциясе үзенчәлекләре. Басылып чыкмаган магистрлык диссертациясе, Гази Университеты, Ижтимагый фәннәр институты. Әнкара, 2001. (төрек телендә).

Зәйдулла P. Beyaz Hırkalı İhtiyar / Р.Зәйдулла. Ак япанчалы карт / тәрж. Ф.Кутлу. Анкара: "Бәнгү" нәшр., 2016. 111 б. (төрек телендә).

Казан татарлары куплетлары. Игнац Кунос редакциясендә / тәрж. Мостафа С. Төркия теле институты. Әнкара: Сюзанна Какк нәшерендә, 2013. (төрек телендә).

Каракылыч Акы С. Галиәскар Камалның драма әсәрләрендә тел һәм стиль. Кандидатлык диссертациясе, Гази университеты, Ижтимагый фәннәр институты. Әнкара, 2013. (төрек телендә).

Карталжык B. Шәриф Камалның «Акчарлаклар» һәм «Таң атканда» әсәрләрендәге тел үзенчәлекләре (кереш - текстның библиографик күрсәткече). Басылып чыкмаган кандидатлык диссертациясе, Эге университеты, Ижтимагый фәннәр институты. Измир, 2008. (төрек телендә).

Косе A. Ринат Мөхәммәдиевнең «Кенәри читлек кошы» әсәренең тәржемәсе һәм анда сыйфатларның hәм фигыльләрнең роле, татар-төрек теле үзенчәлекләре. Басылып чыкмаган магистрлык диссертациясе, Челал Баяр университеты, Ижтимагый фәннәр институты. Маниса, 2007. (төрек телендә).

Курбан Р. Мөхәмммәт Мәһдиевнең «Торналар төшкән жирдә» повестенда Казан татар горефгадәтләре // Төрек дөньясы Тел һәм әдәбият журналы. 2019. № 47. Б. 177-194. (төрек телендә). 
Курбан Р. Сөй тормышны, сөй гомерне, сөй милләтнең дөньясын // Төрә. 2016, № 36, 42. (төрек телендә).

Курбан Р. Сталин дәвере һәм корбаннары // Без Иделдән, Уралдан... 2014. Б. 90-98. (төрек телендә).

Курбан Р. Татар әдәбиятында тарихи романнар // Без Иделдән, Уралдан... Истанбул, 2014. Б. 195215. (төрек телендә).

Курбан Р. Татар әдәбиятының бөек имәне Әмир хан Еники (1909-2000) // Без Иделдән, Уралдан.. 2014. Б. 140-151. (төрек телендә).

Курбан Р. Татар зыялысы Каюм Насыйрины искә алганда // Без Иделдән, Уралдан... Истанбул. 2014. Б. 34-54. (төрек телендә).

Курбан Р. Татар шигырь дөньясының армасталмас көрәшчесе Нәжибә Сафина // Өнжә Ватан. 2019. 27 май. Б. 9-10. (төрек телендә).

Курбан P. Тууының 150 елында татар әдәбиятының философ шагыйре Дәрдмәнд // Без Иделдән, Уралдан...2014. Б. 65-80. (төрек телендә).

Курбан Р. Тууының 160 елында Дәрдмәнднең тормыш юлы һәм ижаты // Төрек дөньясы Тарих, мәдәният журналы. 2019. № 390. Б. 52-59. (төрек телендә).

Курбан Р. Үлүенең 90 елында Дәрдмәнд // Без Иделдән, Уралдан...2014. Б. 81-90. (төрек телендә).

Кучук Мәхмәтогль О. Муса Бигиевның «Дивани Хафиз» хикәясендәге лексик терминнарга анализ, Басылып чыкмаган магистрлык диссертациясе, Гази университеты, Ижтимагый фәннәр институты. Әнкара, 2010. (төрек телендә).

Мемиш С. Зөлфәт шигырьләренә анализ (кереш, текстның библиографик күрсәткече). Басылып чыкмаган магистрлык диссертациясе, Эге университеты, Ижтимагый фәннәр институты. Измир, 2012. (төрек телендә).

Мирза М. Адәм баласы: шигырьләр. Татарча, русча, төрекчә, инглизчә / тәрж. Ч. Зариф и Ф. Кутлу. Казан: Мәгариф, 2009. 448 б. (төрек телендә).

Мөхәммәдиев Р. Россия демократиясе / тәрж. М. Онер. 1996, Мөстәкыйль басмалар. (төрек телендә).

Мөхәммәдиев Р. Сират күпере. Солтангалиев / тәрж. М. Онер. Төркия Бөтендөнья нәшрият фонды. № 109, Истанбул, 1993.

Озкан Ф. Габдулла Тукай шигырьләре, текстны анализлау - тәржемә итү. Әнкара: Төркия мәдәният фәнни-тикшерену институты нәшрияты, 1994. (төрек телендә).

Озмен О. Галимжан Ибраһимовның «Казах кызы» (кереш - текстның библиографик күрсәтмәсе). Басылып чыкмаган магистрлык диссертациясе, Эге университеты, Ижтимагый фәннәр институты. Измир, 2006. (төрек телендә).

Озчобан Й. Ибраһим Сәлаховның «Колыма хикәяләре» hәм "Күкчәтау далаларында" романнары (кереш - текст - сүзлек һәм библиографик күрсәтмә). Басылып чыкмаган кандидатлык диссертациясе. Истанбул университеты, Ижтимагый фәннәр институты. Балыкесир, 2008. (төрек телендә).
Онер М. Габдулла Тукай шигырьләре. Басылып чыкмаган магистрлык диссертациясе. Университет Докуз Эйлул, Ижтимагый фәннәр институты. Измир,1990. (төрек телендә).

Онер М. Татар икеюллыклары, Кум Саати басмалары. Истанбул, 2005

Полат У. Сибгат Хәким шигырьләре (кереш текстның библиографик күрсәткече). Басылып чыкмаган магистрлык диссертациясе, Эге институты, Ижтимагый фәннәр институты. Измир, 2011. (төрек телендә).

Сәлахов И. Колыма хикәяләре. Татар интеллигенциясенең сөргендәге истәлекләре / тәрж. Й. Озчобан. Конья: Комен нәшрияты, 2013. (төрек телендә).

Tonчy $X$. Ризаэтдин бин Фәхретдиннең «Әхмәд Мидхәт әфәнде» хезмәтенә анализ. Басылмаган магистрлык диссертациясе, Гази университеты, Ижтимагый фәннәр институты. Әнкара, 2009. (төрек телендә).

Тукай Г. Кайту: шигырьләр / төрек теленә тәрж. Б. Орух Аслан, Й. Озчобан. № 117. Конья, 2014 (төрек телендә).

Турхан Арслан C. Татар - төрек теле. Рәзил Вәлиев - Трагедия (анализ-текст-сүзлек). Басылып чыкмаган магистрлык диссертациясе, Фират университеты, Ижтимагый фәннәр институты Элязыг, 2006. (төрек телендә).

Услу А. “Татар әдәбиятында заманча романнар hәм әкиятләр (XIX гасыр ахыры XX гасыр башы)”. Басылып чыкмаган докторлык диссертациясе, 2004. (төрек телендә).

Фәхретдин Р. Әхмәд Мидхәт әфәнде. Оренбург: «Вакыт» матбагасы, 1913. 144 б. (татар телендә).

Шаһин Э. Татар жырлары жыентыгы (кереш текстның библиографик күрсәткече). Әнкара: Төркия теле ассоциациясе нәшрияты, 1999. (төрек телендә).

Ширин Х. Хәсән Туфан шигырьләре, кереш сүзлек. Басылып чыкмаган магистрлык диссертациясе, Эге университеты, Ижтимагый фәннәр институты. Измир, 1998. (төрек телендә).

Эрии Сойтурк Ф. Мәжит Гафури шигырьләре (кереш-текст - текстның библиографик күрсәткече). Басылып чыкмаган магистрлык диссертациясе, Эге университеты, Ижтимагый фәннәр институты, Измир, 2006. (төрек телендә).

Abdullah Tukay. Şiirler / Габдулла Тукай: шигырьләр / тәрж. А. Акбаш, Ф. Кутлу. Анкара: «Бәнгү» нәшр., 2016. 224 б.(төрек телендә).

Altın Sincap / Алтын тиен: Балалар өчен хикәяләр жынтыгы / тәрж. Ф. Кутлу. Анкара: «Бәнгү» нәшр., 2014. 293 б. (төрек телендә).

Bargan H. Şemseddin Sami ve İdil-Ural tatarlari // Türkiyat Mecmuas1, c. 26/1, 2016. S. 51-60. (төрек телендә).

Bargan H. Yenileşme dönemi türk edebiyatı'nın İdil-Ural bölgesi tatar edebiyatı'na etkisi (1860-1917) [Яңарыш чоры төрек әдәбиятының Идел-Урал буе 
татар әдәбиятына йогынтысы]. Doktora Tezi, İstanbul 2015. (төрек телендә).

Fildişi Çakı / Сөяк саплы пәке: Балалар хикәяләре жыентыгы / тәрж. Ф. Кутлу. Анкара: «Бәнгү» нәшр., 2013. 168 б. (төрек телендә).

Garipov M. Ebedi Așk. Abdullah Tukay ve Zeytüne Mevlüdova Hikayesi / Tatar Türkçesinden Türkiye Türkçesine Çev. Ç. Zaripova-Çetin ve Hayati Yılmaz. Ankara: Bengü Yayınları, 2016.103 с. (төрек телендә).

Ğlylecev A. Bir Avuç Toprak / А. Гыйләжев. Өч аршын жир) / тәрж. Ф. Кутлу. Анкара: "Бәнгү" нәшр., 2013. 113 б. (төрек телендә).

Ğlylecev A. Cuma günü, akşam... / А. Гыйләжев. Жомга көн, кич белән... / тәрж. Ф. Кутлу. Анкара: «Бәнгү» нәшр., 2013. 202 б. (төрек телендә).

Íshaki A. Hikayeler (Seçmeler). Tatar Türkçesinden Türkiye Türkçesine aktaran Çulpan Zaripova-Çetin, Hayati Yılmaz. Muğla: Muğla Üniversitesi Yayınları, 2009. 181 s. (төрек телендә).

Sessiz Kuray / Тавышсыз курай: повесть һәм хикәяләр жыентыгы / тәрж. Ф. Кутлу. Анкара: «Бәнгү» нәшр., 2013. 190 б. (төрек телендә).

Vasiyet / Васыять: повесть һәм хикәяләр жыентыгы / тәрж. Ф. Кутлу, h. Әрсой-Надир, Т. Арслан. Истамбул: «Замбак» нәшр., 2012. 111 б. (төрек телендә).

Zaripova-Çetin Ç. A. İbrahimov'un Eserlerinde Tatar, Başkurt ve Kazak Türklerinin Kültürel Değerleri. Ankara: Bengü Yayınları, 2016. 369 s. (төрек телендә).

Zaripova-Çetin Ç. A. İbrahimov'un Kazak Kızı Adlı Romanında Kazak Türklerinin İyiyecek-İçecekleri ve Sofra Adab1 // Великая степь. II. Форум гуманитарных наук. Астана, 2017, 2 книга. С. 235244. (төрек телендә).

Zaripova-Çetin Ç. Kazan Tatar Manilerinde Kadınların Talihsiz Kaderi // Atatürk Üniversitesi Türkiyat Araştırmaları Enstitüsü Dergisi (TAED) Journal Of Turkish Research İnstitute. 2016 (57). S. 1619-1636. (төрек телендә).

Zaripova-Çetin Ç. Ö. Beşirov, A. Şamov ve M. Mehdiyev'in Eserlerinde Tatar Türklerinin Milli Değerleri // VI. Uluslararası Büyük Türk Dili Kurultayı
Bildirileri (25-28 Eylül 2011 Erzurum). Ankara 2011. S. 251-261. (төрек телендә).

Zaripova-Çetin Ç. Şimalde Şark Gülleri Yetiştiren Şair Redif Gataş // Kardeş Kalemler, Sayı 22, Ekim 2008. S. 64-72. (төрек телендә).

Zaripova-Çetin Ç. Tatar Folklor ve Halk Edebiyatında Kayın Ağacı // Turkish Studies International Periodical For the Languages, Literature and History of Turkish or Turkic, 2009. S. 583-601. (төрек телендә).

Zaripova-Çetin Ç. Tatar Halk Destanı «İdegey»de Geçiş Dönemleri // Karadeniz Araştırmaları (Balkan, Kafkas, Doğu Avrupa ve Anadolu İncelemeleri) Dergisi. Kara M, 2007, N-15, Gьz. S. 125-149. (төрек телендә).

Zaripova-Çetin Ç. Tatar Şairi Abdullah Tukay in Şiirlerinde Kuran Motifleri // Kardeş Kalemler, Nisan 2011, № 52. S. 40-45. (төрек телендә).

Zaripova-Çetin Ç. Tatar Türklerinin Gelenek ve Görenekleri. Ankara: Karadeniz Dergisi Yayınları, 2009. 160 с. (төрек телендә).

Zaripova-Çetin Ç. Tatar Yazar Fevziye Beyremova'nın Edebi Kişiliği ve «Cengiz Aytmatov'un Tatar Annesi»» Adlı Kitabı Üzzerine // Kardeş Kalemler, 2019, N- 149 (Mayıs). S. 64-72. (төрек телендә).

Zaripova-Çetin Ç. Tatar Yazarı Mirgazıyan Yunus'un Seyahatnamelerinde İstanbul // I. Uluslar arası Türk Edebiyatında İstanbul Sempozyumu (03-05 Nisan 2008) Bildirileri. İstanbul 2009. S. 261-271. (төрек телендә).

Zaripova-Çetin Ç. Vatan Цzlemi Konulu Tatar Manileri // IV.ULuslararası Türk Medeniyetinde Sözlü Kültür Geleneği Sempozyum Bildirileri. Maniler. İzmir: Sistem Serigrafi ve Matbaacilık, 2007. S. 212-220. (төрек телендә).

Zaripova-Çetin Ç. Vefatının 80. Yılında Saygıyla Anıyoruz: Alimcan İbrahimov (1887-1938) // Kardeş Kalemler, 2018, Şubat. S. 79-86. (төрек телендә).

Zaripova-Çetin Ç. Alimcan İbrahimovun Almaçuar Adlı Eserinde Tatarların Milli Bayramı Sabantuy // Uluslararası Türk Kültürü Sempozyumu ve Karma Türk Sanatları Sergisi. Makedonya-Üsküp. Ankara, 2017. S. 58-66. (төрек телендә). 


\section{ТАТАРСКАЯ ЛИТЕРАТУРА В ТУРЦИИ: ОСОБЕННОСТИ БЫТОВАНИЯ И ИЗУЧЕНИЯ}

\section{Бирсел Оруж Аслан,} Университет Балыкесир, Турция, 10145, г. Балыкесир, ул. Дорога Бигадич, д. 17, rezeda_raf@mail.ru.

Резеда Рафаилевна Хайретдинова,

Казанский федеральный университет, Россия, 420008, г. Казань, ул. Кремлевская, д. 18, rezeda_raf@mail.ru.

Йусуф Озчобан, Университет Балыкесир, Турция, 10145, г. Балыкесир, ул. Дорога Бигадич, д. 17, rezeda_raf@mail.ru.

Айслу Хусяиновна Садекова, Институт языка и литературы им. Г. Ибрагимова АН РТ, Россия, 420008, г. Казань., ул. К.Маркса, д. 12, rezeda_raf@mail.ru.

В статье содержится материал о бытовании татарской литературы в Турции и путях ее популяризации и изучения. Особое внимание уделяется темам и проблематике научных работ. Выявлены работы ученых, внесших огромный вклад в популяризацию татарской литературы в Турции, духовного наследия в среде братского тюркского народа. Дана оценка уровню литературоведческих научных работ, посященных изучению поэтики татарской литературы, приведены статистические данные. Определены перспективы дальнейших исследований в области изучения татарской литературы в Турции.

Ключевые слова: татарская литература, Турция, литературоведение, литературные взаимосвязи, перевод, развитие. 